\title{
Synthesis of pyrrolizidines and indolizidines by multicomponent 1,3-dipolar cycloaddition of azomethine ylides
}

https://doi.org/10.1515/pac-2018-0710

\begin{abstract}
Different multicomponent 1,3-dipolar cycloadditions (1,3-DC) of cyclic $\alpha$-amino acid derivatives with aldehydes and dipolarophiles have been described as efficient and simple methodologies for the synthesis of the pyrrolidine unit of pyrrolizidines and indolizidines. When free cyclic $\alpha$-amino acids are used, a thermal promoted decarboxylative process generates in situ the corresponding non-stabilized azomethine ylides, which afforded the corresponding pyrrolizidines and indolizidines with a hydrogen in the bicyclic units. This methodology has been employed to the synthesis of complex systems including spiro derivatives when ketones are used as carbonyl component. In addition, working with cyclic $\alpha$-amino acid derived esters, the three-component 1,3-DC takes place under milder reaction conditions giving the corresponding pyrrolizidines and indolizidines with an alkoxycarbonyl group in the bridge adjacent carbon to the nitrogen. This methodology can be carried out by a double consecutive or stepwise 1,3-DC to provide pyrrolizidines via the precursor prolinates. The conformation of the azomethine ylide controls the endo/exo diastereoselectivity of the 1,3-DC.
\end{abstract}

Keywords: 1,3-dipolar cycloadditions; azomethine ylides; carbonyl compounds; Distinguished Women in Chemistry and Chemical Engineering; electrophilic alkene; iminium ions; indolizidines; multicomponent reactions; pyrrolizidines.

\section{Introduction}

Natural and non-natural pyrrolizidine [1] and indolizidine [2] alkaloids show important biological properties especially polyhydroxylated systems, which are potentially glycosidase inhibitors and have antibacterial, antitumor, antiviral, anti-inflammatory and immunostimulatory properties (Fig. 1). For these reasons many synthetic strategies have been described being the intermolecular three-component 1,3-dipolar cycloaddition (1,3-DC) of azomethine ylides the most efficient approach for the generation of the common pyrrolidine unit in a single reaction step [3-6]. This multicomponent reaction (MCR) involves the formation of a dipole formed by an iminium anion adjacent to a carbanion, by reaction of a cyclic amino acid with a carbonyl compound, which is trapped by a dipolarophile. This 1,3-DC can take place through two strategies depending on the amino acid derivative: (a) starting from the free amino acid, and (b) from the amino ester (Scheme 1). In the first case, a decarboxylative condensation occurs with the formation of a non-stabilized azomethine ylide, whereas in the second case a stabilized azomethine ylide is involved. Usually, the first multicomponent

\footnotetext{
*Corresponding author: Carmen Nájera, Departamento de Química Orgánica and Centro de Innovación en Química Avanzada (ORFEO-CINQA), Universidad de Alicante, Apdo. 99, Alicante 03080, Spain, e-mail: cnajera@ua.es José Miguel Sansano: Departamento de Química Orgánica and Centro de Innovación en Química Avanzada (ORFEO-CINQA), Universidad de Alicante, Apdo. 99, Alicante 03080, Spain; and Instituto de Síntesis Orgánica, Universidad de Alicante, Apdo. 99, Alicante 03080, Spain
} 
<smiles>OC[C@H]1[C@@H](O)[C@H](O)[C@H]2[C@@H](O)[C@@H](O)CN12</smiles>

Casuarine<smiles>OC[C@H]1C(O)CN2CCC(O)[C@H]12</smiles>

Rosmarinecine<smiles>OC1CCN2C[C@H](O)[C@@H](O)[C@H](O)C12</smiles>

Castanospermicine<smiles>C[C@]12C(O)CCN1[C@@H](CO)[C@@H](O)[C@@H]2O</smiles>

Australine<smiles>OCC1=CCN2CC[C@H](O)[C@H]12</smiles>

Heliotridine<smiles>O[C@H]1CCCN2C[C@@H](O)[C@H](O)[C@@H]12</smiles>

Swainsonine<smiles>OC[C@@H]1CCN2CCC(O)[C@H]12</smiles>

Hastanecine<smiles>OCC1=CCN2CC(O)[C@H](O)[C@H]12</smiles>

Crotanecine<smiles>O[C@H]1CN2CCCCC2[C@H]1O</smiles>

Lentiginosine

Fig. 1: Selected pyrrolizidine and indolizidine alkaloids.

reaction must be performed under heating, where the second one needs milder reaction conditions. In this minireview, we highlight the development of intermolecular MCR 1,3-DC of azomethine ylides focused to the synthesis of pyrrolizidines and indolizidines including our contributions in this field, covering from its origin to recent contributions.

a
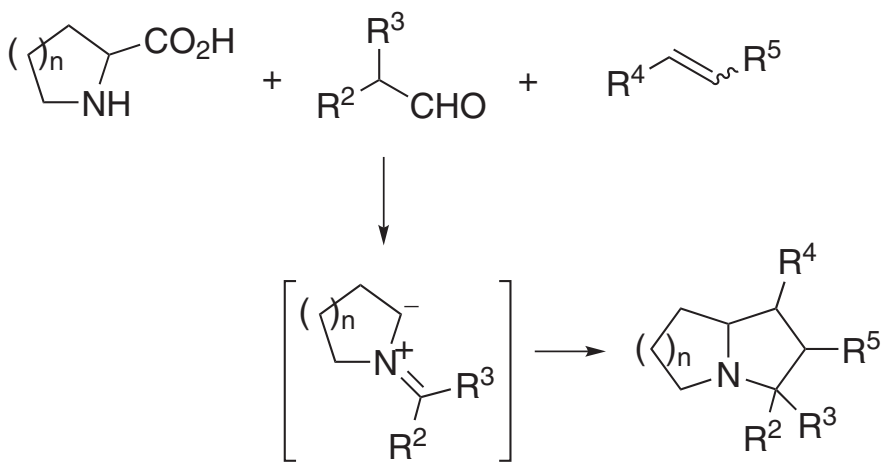

b
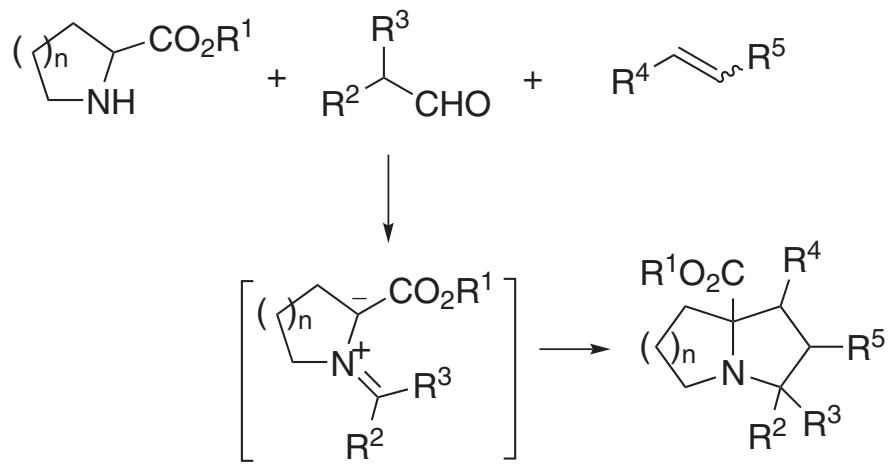

Scheme 1: Strategies for three-component 1,3-DC. 


\section{Multicomponent synthesis of pyrrolizidines by decarboxylative}

\section{1,3-DC}

Since the pioneering work of Grigg and co-workers [7] the decarboxylative routes of azomethine ylides has been widely used in 1,3-DC. This process can involve an intermediate oxazolidin-5-one, which loses carbon dioxide in a 1,3-dipolar cycloreversion reaction generating the non-stabilized azomethine ylide, but also by a 1,4-protropic rearrangement of the azomethine ylide [8-10]. The groups of Grigg et al [9, 10] and Orsini et al [11] described the synthesis of pyrrolizidines by MCR of proline with aldehydes and electrophilic olefins leading to mixtures of diastereomers. For instance, using benzaldehyde and $N$-propargyl maleimide under toluene reflux for $20 \mathrm{~h}$ a 3:1 mixture of endo/exo pyrrolizidines 1 were obtained via the anti-dipole I (Scheme 2) [12].

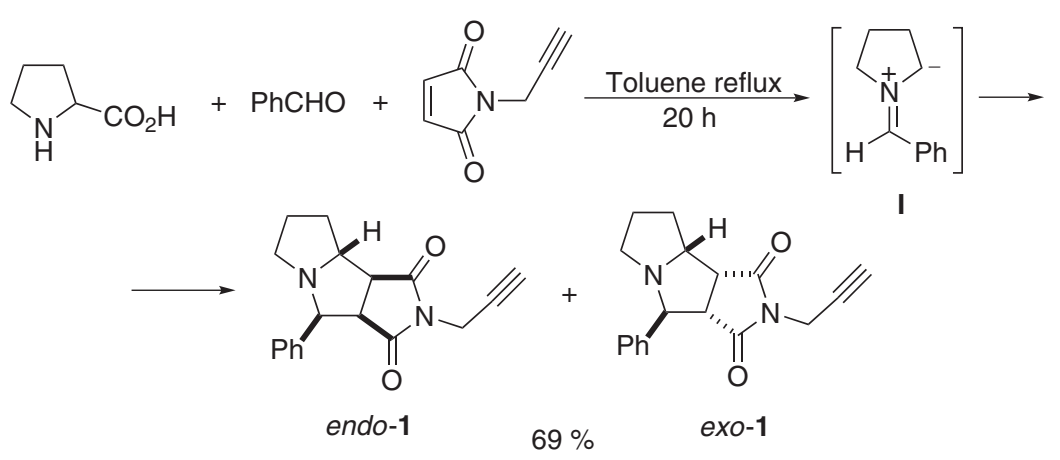

Scheme 2: Multicomponent 1,3-DC of proline, benzaldehyde and $\mathrm{N}$-propargyl maleimide.

Further applications of this process are depicted in Fig. 2. A four-component reaction of nihydrin, 1,2-phenylenediamine, proline and $N$-aryl maleimides gave after microwave (MW) irradiation (3-5 min at $600 \mathrm{~W}$ ) exo-spiropyrrolizidines 2 in 85-95\% yield through intermediacy of azomethine ylide II [13]. Dispiroindenoquinoxaline-pyrrolizidine derivatives 3-6 have been prepared by subsequent in situ reaction of nihydrin with 1,2-phenylenediamine, then addition of L-proline and as carbonyl component: 2-arylidene-1,3-indanone, $(E)$ 2-arylidenetetrahydronaphthalene-1-ones, (E)-3-arylidene-4-chromanones and (E)-2-oxoindolino-3-ylidene

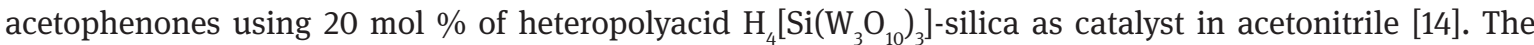
same group described the synthesis of spiroheterocycles 7 by a three-component, under solvent free MW irradiation of proline, nihydrin and 9-arylidenefluorenes in high yields by means of azomethine ylides III derived from nihydrin [15]. Other spiro derivatives 8-10 (Fig. 2) have been synthesized using as cyclic ketones nihydrin, $11 H$-indeno[1,2-b]quinoxalin-11-one and acenaphthenequinone, respectively, being azomethine ylides II-IV the corresponding intermediates [16].

Azomethine ylides derived from acenaphthenequinone $\mathbf{I V}$ and isatins $\mathbf{V}$ were the intermediates in the three-component 1,3-DC with a carbohydrate derived olefin providing spiro cycloadducts $\mathbf{1 1}$ and $\mathbf{1 2}$, respectively (Scheme 3) [17].

Perumal and co-workers [18] have described the three-component 1,3-DC of proline with acenaphthenequinone and $\alpha, \alpha^{\prime}$-bisalkylidenepyridinones under refluxed methanol affording spiropyrido-pyrrolizidines 13 in high yields (Fig. 2). Acenaphthenequinone has been allowed to react with proline and (E)-2-oxoindolino3-ylidene acetophenones using MW irradiation and mediated by $\mathrm{ZrOCl}_{2} \cdot 8 \mathrm{H}_{2} \mathrm{O}$ giving mainly products 14 [19] (Fig. 2). Nihydrin has been used as carbonyl component in the synthesis of spiropyrrolizidines 15 and 16 in the presence of chalcones and nitrostyrenes, respectively in methanol at rt [20] (Fig. 2). Korotaev and coworkers used 3-nitro- $2 \mathrm{H}$-chromenes as dipolarophiles leading to the formation of the corresponding spiropyrrolizidines 17 in good yields upon heating in ethanol [21] (Fig. 2).

Isatins have been widely used as carbonyl component for the multicomponent synthesis of spirooxindole-pyrrolizidines with potential biological activity using proline and different dipolarophiles. Raghunathan 
<smiles>[R]c1cc2nc3c(nc2cc1[R])C1(c2ccccc2-c2ccccc21)C1(C(=O)N([Al])C(=O)[C@H]1[CH])[C@H]1CCCN31</smiles>

$2^{[13]}, 89-95 \%$

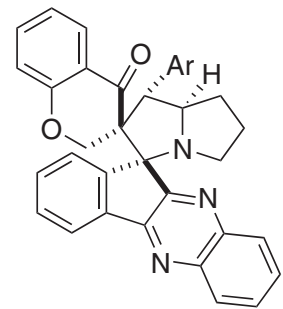

$5^{[14]}, 85-88 \%$<smiles>O=C1c2ccccc2C(=O)C12C1c3ccccc3S(=O)(=O)[C@H]1C1CCCN12</smiles>

$8^{[16]}, 79 \%$<smiles>[R]c1cc2nc3c(nc2cc1[R])-c1ccccc1C3=[N+]1CCCC1</smiles>

II<smiles>O=C1Nc2ccccc2C12C(=O)Nc1ccccc12</smiles>

$6^{[14]}, 85-88 \%$<smiles>O[Sb]1c2ccccc2C2c3ccccc3[C@]21c1nc2ccccc2nc1-c1ccccc1</smiles>

$\mathbf{9}^{[16]}, 81 \%$<smiles></smiles>

$3^{[14]}, 86-92 \%$<smiles>O=C1c2ccccc2C(=O)C12N1CCCC1C(Br)C21c2ccccc2-c2ccccc21</smiles>

$7^{[15]}, 81-93 \%$<smiles>O=C1c2cccc3cccc(c23)[C@]12[C@H]1c3ccccc3OS(=O)(=O)[C@H]1[C@@H]1CCCN12</smiles>

$10^{[16]}, 83 \%$<smiles>O=C1c2ccccc2CC[C@]12C[C@@H]([AlH])[C@@H]1CCCN1[C@]21c2ccccc2-c2nc3ccccc3nc21</smiles>

$4^{[14]}, 85-88 \%$<smiles>O=c1c(=[N+]2CCCC2)c(=O)c2ccccc12</smiles>

III<smiles>O=C1C(=[N+]2CCCC2)c2cccc3cccc1c23</smiles>

IV

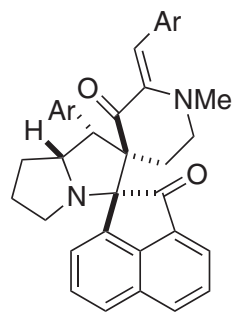

$13^{[18]}, 95-97 \%$

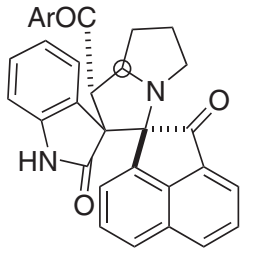

$14^{[19]}, 84-87 \%$<smiles>O=C(Oc1ccccc1)C1NCCCCC2(C(=O)c3ccccc3C2=O)[C@H]1C(=O)c1ccccc1</smiles>

$15^{[20]}, 75-84 \%$

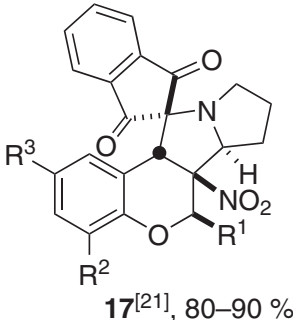

Fig. 2: Spiro-fused pyrrolizidines and azomethine ylides.

and co-workers firstly described the MCR of isatin with proline and 9-arylidenefluorene in a solvent-free MW assisted 1,3-DC affording the corresponding dispiro-oxindole-pyrrolizidines in very good yields 18 [22] (Fig. 3). Working under ultrasonication in the presence of silica as a catalyst dispiro-oxindole-pyrrolizidines 19 were formed using alkylidene-oxindoles as dipolarophile in acetonitrile [23] (Fig. 3). These reaction conditions were applied to the same MCR using nihydrin as carbonyl component. In the case of spirooxindoles 


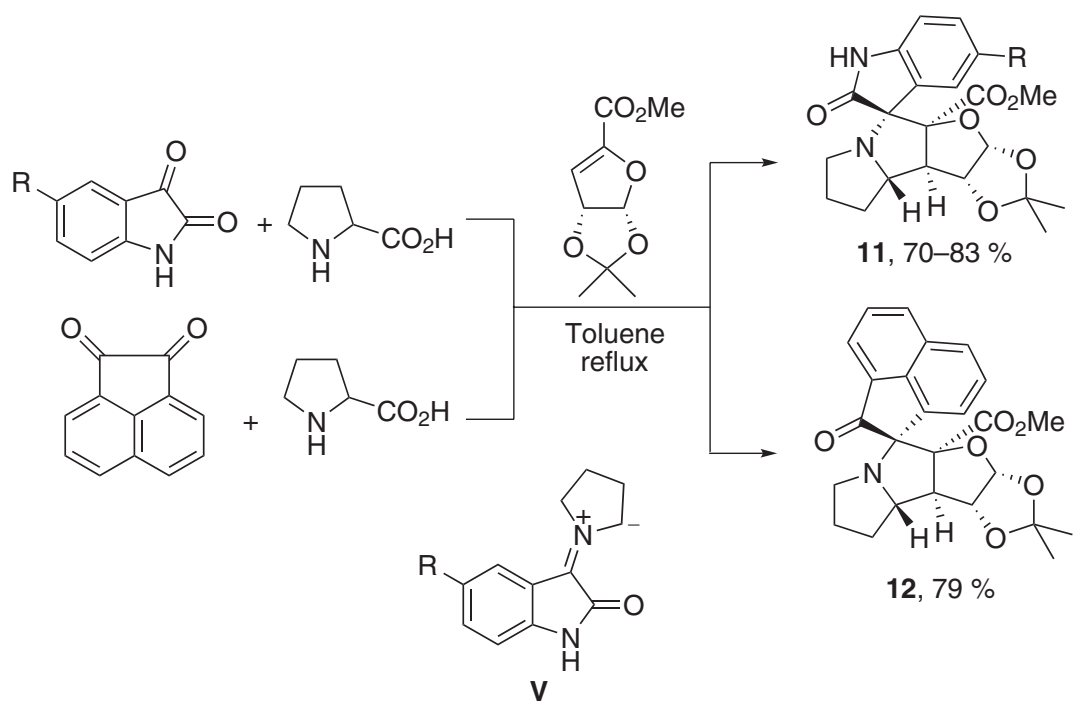

Scheme 3: Three-component 1,3-DC of proline with isatins or acenaphthenequinone and a sugar-derived olefin.

20 the pyrrolizidine unit has been prepared using benzo[b]thiophene dioxide under refluxing methanol for 45-110 min [16]. In this case the azomethine ylide $\mathbf{V}$ is participating giving only one regioisomer through the approach represented in Scheme 4.<smiles>[R]c1ccc2c(c1)C(=O)C(=O)N2CCOc1cc2ccccc2s1</smiles>

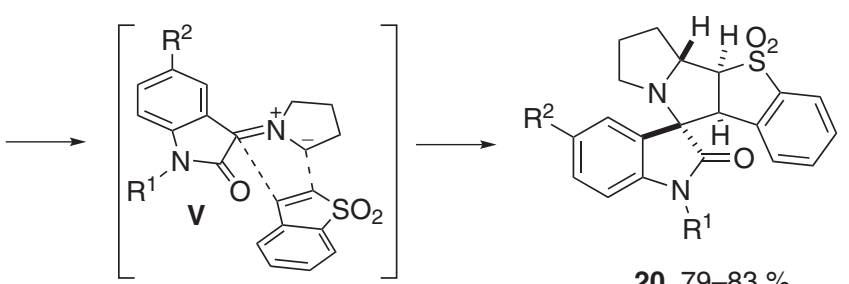

$20,79-83 \%$

Scheme 4: Three-component 1,3-DC of isatins, proline and benzo[b]thiophene dioxide.

For the synthesis of spirooxindoles $\mathbf{2 1}$ the sugar-derived $\alpha, \beta$-unsaturated lactones were employed as dipolarophiles under refluxing toluene by intermediacy of azomethine ylide $\mathbf{V}$ [24] (Fig. 3). Glyco-3-nitrochromenes $\mathbf{2 2}$ have been used as dipolarophiles by the same group in the MCR of isatin and proline under refluxing acetonitrile affording pyrrolidinyl spirooxindoles 23 [25] (Fig. 3). They also employed acenaphthalenones and indenoquinoxalines as carbonyl components affording the corresponding glycol 3-nitrochromane hybrid pyrrolizidinyl spiro-derivatives in 81-84\% yield. Babu and co-workers have employed the Diels-Alder cycloadduct 24, derived from furan and methyl maleate, as dipolarophile in the three-component 1,3-DC of isatins and proline under refluxing ethanol or in a mixture of ethanol and 1,4-dioxane. The resulting norbornane-fused spirooxindolo-pyrrolizidines 25 were obtained in moderate yields [26] (Fig. 3). When (E)-3-benzylidenechroman-2-ones $\mathbf{2 6}$ were used as dipolarophiles the corresponding dispirooxindole-pyrrolizidines $\mathbf{2 7}$ were obtained under refluxing toluene in high yields [27] (Fig. 3). Yang and co-workers have used 1-benzyl3-acetonylideneoxindole $\mathbf{2 8}$ as dipolarophile for the three-component 1,3-DC of $N$-benzylisatin and proline. The reaction took place at $\mathrm{rt}$ in methanol providing the dispirooxindole derivative 29 in high yield [28] (Fig. 3). The cycloadducts 30, derived from $\beta$-nitrostyrene, have been prepared from isatins and L-proline as well as 

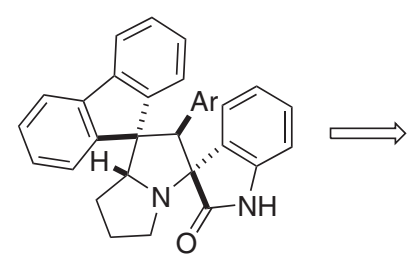

$18^{[22]}, 80-96 \%$

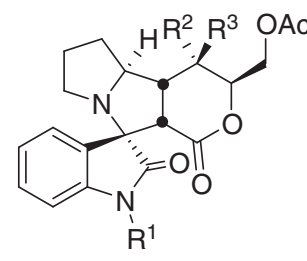

$21^{[24]}, 80-88 \%$

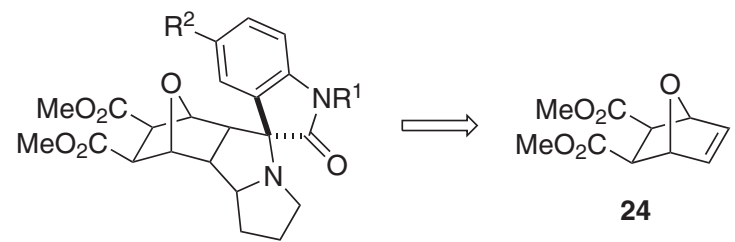

$25^{[26]}, 50-70 \%$<smiles>C=CC(=O)N1CCC2(c3ccccc31)[C@H]1CCCN1C21C(=O)Nc2ccccc21</smiles>

$29^{[28]}, 82 \%$<smiles>O=C(c1ccco1)[C@H]1[C@@H](Br)[C@H]2CCCN2[C@]12C(=O)Nc1ccccc12</smiles>

$32^{[30]}, 82-90 \%$

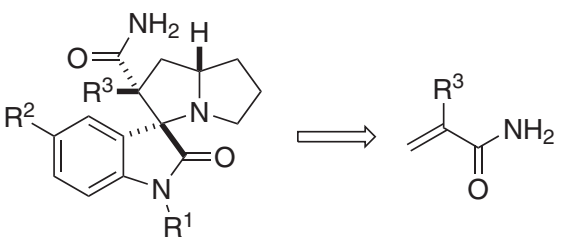

$35^{[32]}, 37-85 \%$

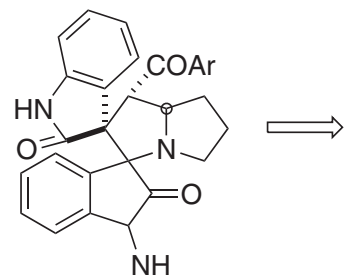

19[23], 86-92\%<smiles>[R7]C1Oc2ccccc2C=C1[N+](=O)[O-]</smiles><smiles>[R]c1ccccc1C1C(=O)OC(=O)C12C(=O)Nc1ccccc12</smiles>

$27^{[27]}, 90-94 \%$<smiles>O=C(Br)/C=C1\C(=O)Nc2ccccc21</smiles><smiles>[R]c1cccc2c1OC(=O)/C(=C/Br)C2</smiles>

26

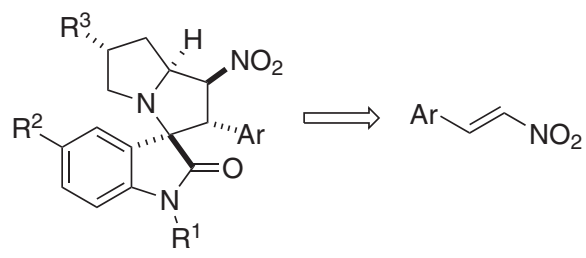

$30^{[29]}, 73-93 \%$<smiles>C=CC[C@@H]1C(C(=O)c2ccccn2)[C@@]2(C(=O)Nc3ccccc32)N2CCC[C@H]12</smiles>

$34^{[31]}, 76-87 \%$

33

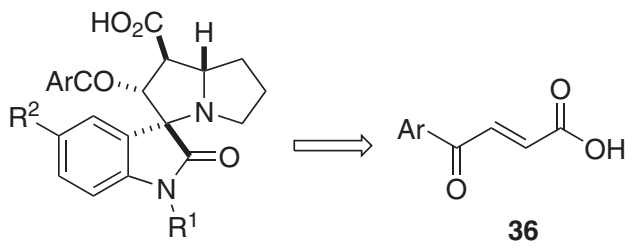

$37^{[32]}, 57-76 \%$

Fig. 3: Spirooxindole-pyrrolizidines. 

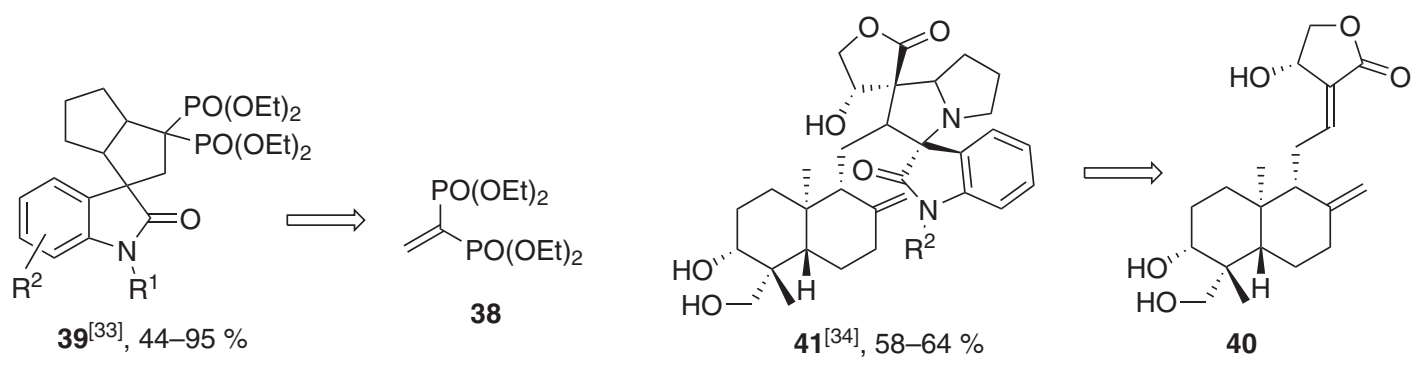

Fig. 3: (Continued)

(4S)-4-hydroxy-L-proline in a mixture of propylene carbonate and water as solvents at $90^{\circ} \mathrm{C}$ in very good yields [29] (Fig. 3). From LC $_{50}$ toxicity assays in zebrafish embryos, three molecules were identified as the most hepatotoxicity derivatives. By using $\alpha, \beta$-unsaturated ketones 31 as dipolarophiles, the three-component 1,3-DC of isatin and proline afforded products 32 in very good yields [30] (Fig. 3). These spirooxindoles 32 bearing the furanyl moiety displayed good in vitro antibacterial activity against Gram-negative bacteria, especially compound 32 with $\mathrm{Ar}=\mathrm{MeOC}_{6} \mathrm{H}_{4}$. Under refluxing methanol, a library of spirooxindole-pyrrolizidine derivatives 34 have been prepared in a MCR using enones 33 as dipolarophiles in good yield [31] (Fig. 3). Spirooxindolepyrrolizidines $\mathbf{3 5}$ and $\mathbf{3 7}$ were obtained using acrylamides and aroyl acrylic acid $\mathbf{3 6}$ as dipolarophiles, respectively [32] (Fig. 3). These MCR were performed in refluxing aqueous methanol (1:3) in moderate to good yield in the case of compounds $\mathbf{3 5}$ and at rt for products $\mathbf{3 7}$. Montmorillonite has been used as a catalyst (10 mol $\%$ ) for the 1,3-DC of isatins, proline and tetraethylvinylidenebis(phosphonate) (38) leading to mixture of spirooxindole-pyrrolizidines 39 in moderate to good yields [33] (Fig. 3). The andrographolide adducts 41 have been prepared under refluxing aqueous methanol (9:1) in moderate yields using angrapholide 40, the major labdane diterpene constituent of the medicinal plant Andrographis paniculate, as dipolarophile [34] (Fig. 3).

The MCR of acyclic 1,2-dicarbonyl derivatives, such as butane-2,3-dione and ethyl pyruvate, with L-proline and $\beta$-nitrostyrene in isopropanol (IPA) at rt gave the corresponding pyrrolizidines $\mathbf{4 2}$ and $\mathbf{4 3}$ as a mixture of regioisomers (Scheme 5) [35]. However, in the case of phenylglyoxal only product 42 was formed. On the
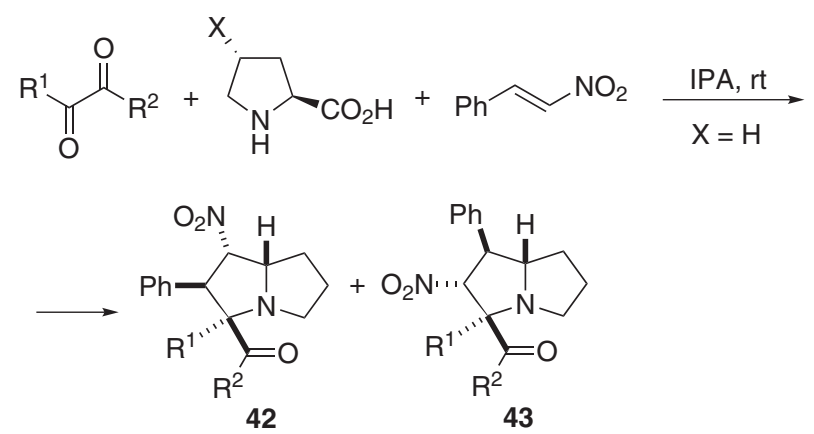

$\mathrm{R}^{1}=\mathrm{R}^{2}=\mathrm{Me}, 87 \%(3: 2)$

$\mathrm{R}^{1}=\mathrm{Me}, \mathrm{R}^{2}=\mathrm{OEt}, 90 \%(9: 1)$

$\mathrm{R}^{1}=\mathrm{H}, \mathrm{R}^{2}=\mathrm{Ph}, 80 \%(100: 0)$<smiles>CC(=O)[C@@]1(C)N2CC(O)C[C@@H]2[C@H](c2ccccc2)[C@@]1(C)C(C)=O</smiles>

44

45

46

Scheme 5: Three-component 1,3-DC of 1,2-dicarbonyl compounds, prolines and $\beta$-nitrostyrene. 


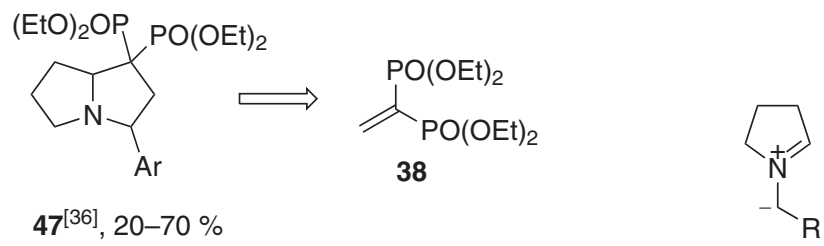
VI<smiles>[R]C1[C@H](C(=O)N2CCOCC2)C([R])N2CCC[C@H]2[C@H]1C(=O)O[Ga]</smiles><smiles>O=C(Br)/C=C/[Al]/C=C\[Te]</smiles>

$50^{[38]}, 65-89 \%$

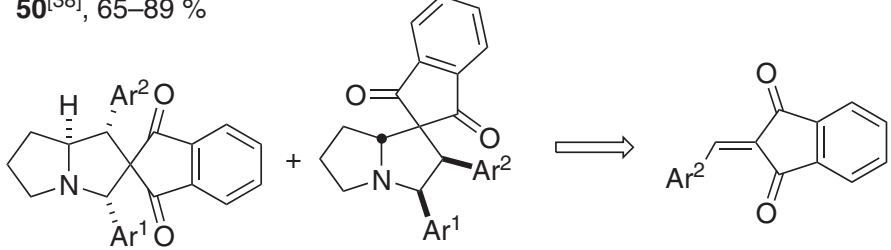

$\mathbf{5 1 ^ { [ 3 9 ] }}, \mathbf{2 0 - 4 2 \%} \quad \mathbf{5 2}^{[39]}, \mathbf{1 9 - 4 1 \%}$

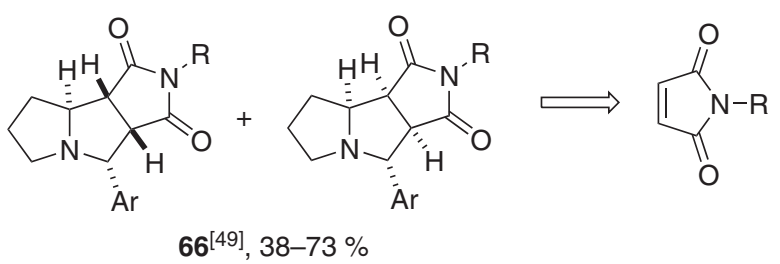

Fig. 4: Pyrrolizidines from L-proline, aldehydes and dipolarophiles.

other hand, (4S)-4-hydroxy-L-proline reacted with butane-2,3-dione giving a 1:4:1 mixture products 44:45:46, respectively, in $78 \%$ overall yield.

$\mathrm{Wu}$ and co-workers used tetraethyl vinylbis(phosphonate) (38) in the three-component 1,3-DC of proline with benzaldehydes in toluene at $80{ }^{\circ} \mathrm{C}$ catalyzed by cerium(IV) oxide ( $5 \mathrm{~mol} \%$ ) leading regioselectively to pyrrolizidines 47 in moderate yields [36] (Fig. 4). Trifluoromethylated pyrrolizidines 49 have been synthetized by reaction of aldehydes, proline and $\beta$-trifluoromethyl acrylamides 48 in DMSO at $80{ }^{\circ} \mathrm{C}$ [37] (Fig. 4). Moderate regioselectivity (up to 1:6) was observed and excellent diastereoselectivity (>20:1) arose for compounds 49 , being the anti-azomethine ylide VI the most stable intermediate according to DFT calculations.

When chalcones were employed as dipolarophiles in dry DMF at $90^{\circ} \mathrm{C}$, endo-adducts $\mathbf{5 0}$ were obtained with excellent regio- and diastereoselectivity [38] (Fig. 4). However, oxazolidines were also formed by reaction of proline with 2 eq. of aldehyde. Both compounds were isolated in 65-89\% overall yields. The MW-promoted $\left(275^{\circ} \mathrm{C}, 300 \mathrm{~W}\right)$ three-component 1,3-DC of proline, aromatic aldehydes and 2-arylmethyleneindene-1,3-dione in 1,4-dioxane provided spiropyrrolizidines 51 and 52 in moderate yields [39] (Fig. 4).

The one-pot sequence aldol condensation of acetone with aldehydes catalyzed by proline, followed by 1,3-DC of the $\alpha, \beta$-unsaturated ketone with proline, afforded racemic pyrrolizidines $53(\mathrm{X}=\mathrm{H})$ in moderate 


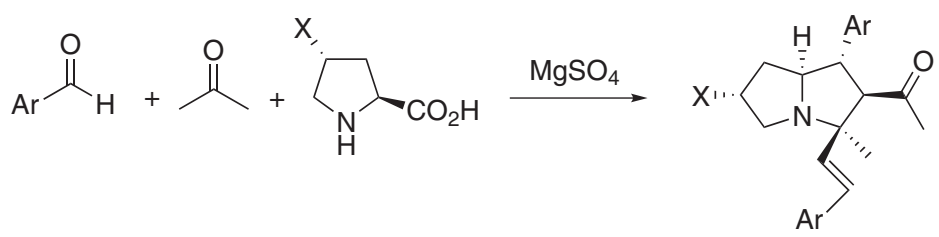

53

$\mathrm{X}=\mathrm{H}, 41-78 \%$

$\mathrm{X}=$ OTBS, $42-52 \%$

Scheme 6: Three-component 1,3-DC of aldehydes, acetone and prolines.

yields (Scheme 6) [40]. The reaction was performed in the presence of $10 \mathrm{~mol} \%$ of $\mathrm{MgSO}_{4}$ in DMSO at rt. Silylated (4S)-4-hydroxy-L-proline lead to the formation of enantiopure products $\mathbf{5 3}$ ( $\mathrm{X}=$ OTBS) in moderate yields.

Diederich and co-workers have prepared several tricyclic thrombin inhibitors by using a decarboxylative 1,3-DC of prolines with benzaldehydes and maleimides [41-46]. The most active were those derived from trans-3-hydroxy-L-proline or trans-4-hydroxy-L-proline with 4-bromobenzaldehyde and $N$-(4-fluorobenzyl)maleimide as the key step (Scheme 7) [45, 46]. In the first case, the 1,3-DC was performed in $\mathrm{MeCN}$ at $80^{\circ} \mathrm{C}$ for $18 \mathrm{~h}$, affording a mixture of separable enantiopure products endo,trans-54 and exo,trans-55 in 24 and $30 \%$, respectively. The same process with trans-4-hydroxy-L-proline in DMF at $80^{\circ} \mathrm{C}$ for $48 \mathrm{~h}$, provided two pairs of inseparable diastereomers, that means, a mixture 1:1 of endoproducts $\mathbf{5 6}$ and $\mathbf{5 7}$ together with a mixture of exo-products $\mathbf{5 8}$ and $\mathbf{5 9}$. The desired product $\mathbf{5 6}$ was further isolated after several transformations.

Our group has recently prepared enantiopure nitropyrrolizidines 61-65 from chiral exo-4-nitroproline 60 [47], aldehydes and dipolarophiles (Scheme 8) [48]. These three-component 1,3-DC took place in toluene at rt or $70^{\circ} \mathrm{C}$, depending on the dipolarophile, affording mixtures of diastereomers with de up to $>99 \%$. In the case of cinnamaldehyde and $N$-methyl or $N$-phenyl maleimides, pyrrolizidines endo-62 were mainly obtained, whereas $N$-(4-bromophenyl)maleimide gave exclusively compound 61 in $80 \%$ yield. Dimethyl

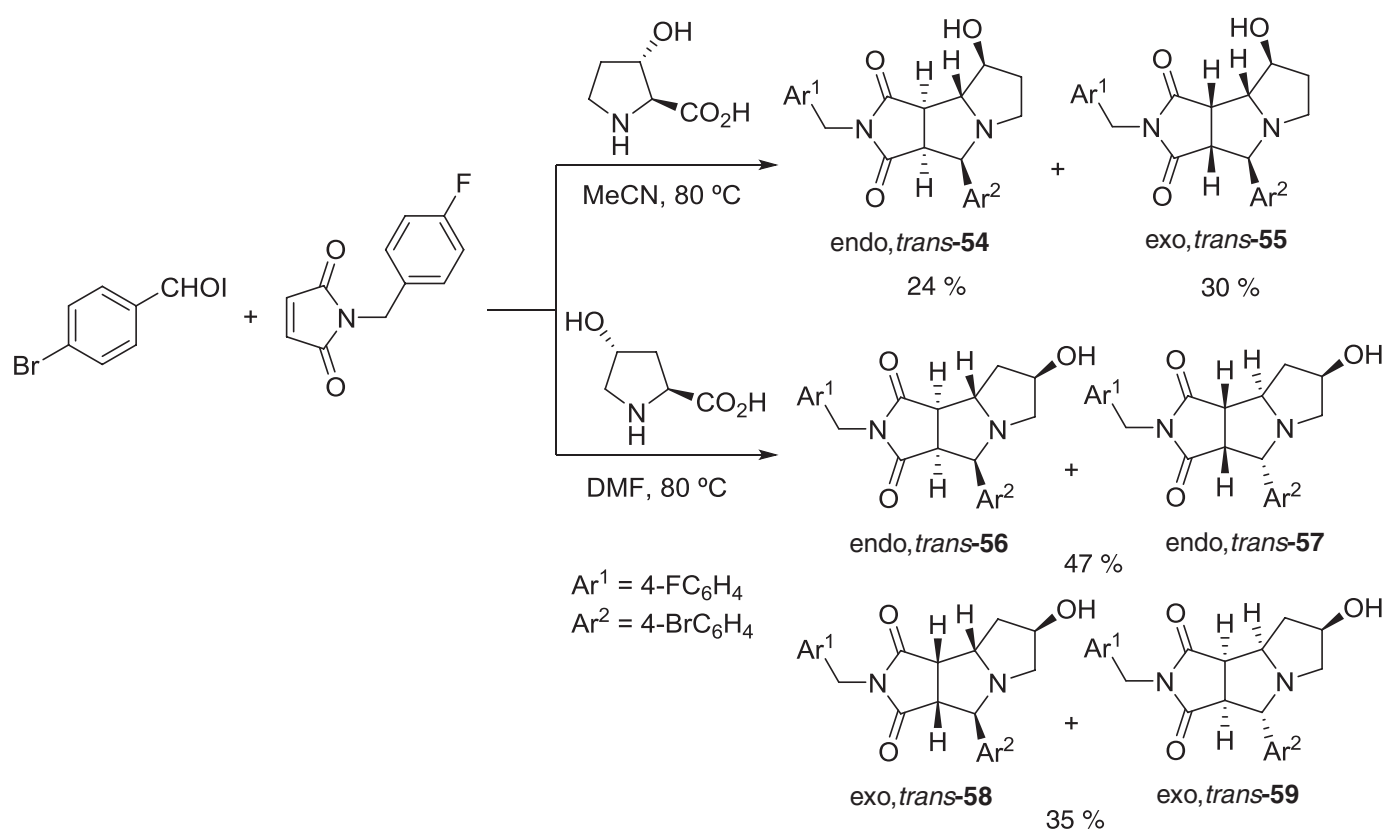

Scheme 7: Three-component 1,3-DC of 4-bromobenzaldehyde, $N$-(4-fluorobenzyl)- maleimide and (3S)- and (4S)-hydroxy-L-prolines. 


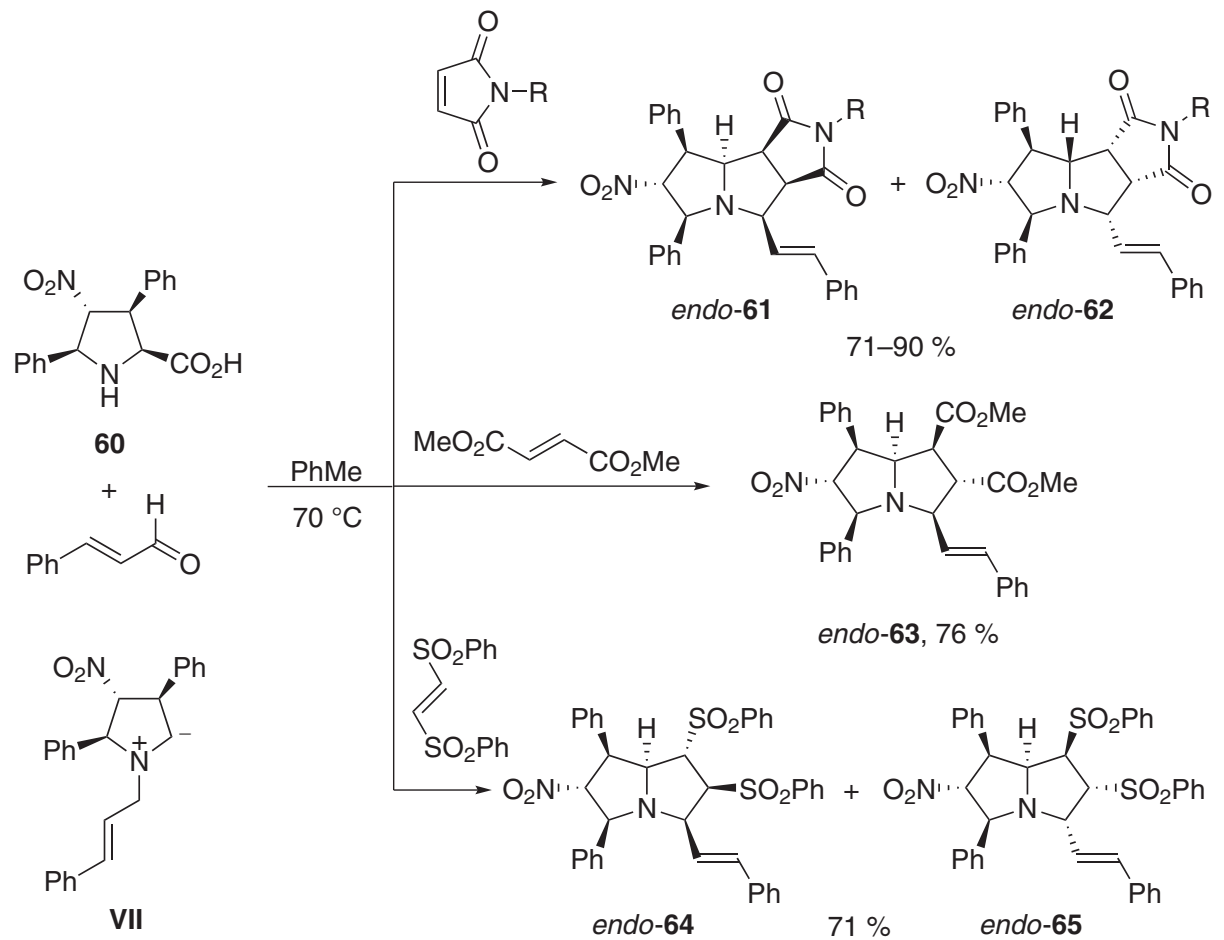

Scheme 8: Multicomponent 1,3-DC of cinnamaldehyde, nitroproline 60 and dipolarophiles.

fumarate also provided exclusively endo-63 and (E)-bis(phenylsulfonyl)ethylene gave a 2:1 mixture of 64 and 65. Other aldehydes, such as benzaldehyde and 3-phenylpropanal, provided compounds $\mathbf{6 1}$ and $\mathbf{6 2}$ in modest yield (23-47\%). In these cases, the endo-selectivity was due to the participation of azomethine ylide VII.

A different multicomponent 1,3-DC has been described by Sridharan and co-workers [49] using benzylic alcohols instead of aldehydes. This reaction must be carried out under Ir catalysis, so a hydrogen autotransfer generated in situ the corresponding aldehyde, which by reaction with proline and maleimide, afforded a $c a$. 1:1 mixture of pyrrolizidines 66 (Fig. 4).

A four-component procedure has been carried out with isatin, proline, 3-(cyanoacetyl)indole and aldehydes under refluxing methanol affording spiropyrrolizidines 67 in moderate yields (Scheme 9) [50]. The corresponding dipolarophiles $\mathbf{6 8}$ were formed in situ via a Knoevenagel condensation between 3-(cyanoacetyl) indole and aldehydes.<smiles>COC(=O)C1CCCN1C(=O)c1c[nH]c2ccccc12</smiles>

68<smiles>C[C@]1(C(=O)c2c[nH]c3ccccc23)C(=O)C2(CCCC2)N2CCC[C@H]21</smiles>

$67,58-65 \%$

Scheme 9: Four-component 1,3-DC of isatin, proline, 3-(cyanoacetyl)indole and aldehydes. 


\section{Multicomponent synthesis of pyrrolizidines by 1,3-DC}

Alkyl prolinate derivatives gave stabilized azomethine ylides by reaction with carbonyl compounds, which can be trapped by dipolarophiles giving substituted pyrrolizidines. Joucla and co-workers have described the three-component 1,3-DC of methyl prolinate with benzaldehyde and methyl $(E)$-cinnamate in refluxing toluene giving, regioselectively, a 1:1 mixture of pyrrolizidines 69 and 70 in $90 \%$ yield (Scheme 10) [51]. The relative configuration of compounds $\mathbf{6 9}$ and $\mathbf{7 0}$ can be attributed to the formation of the azomethine ylide VIII, which attacks to the dipolarophile by the $\alpha$-position.

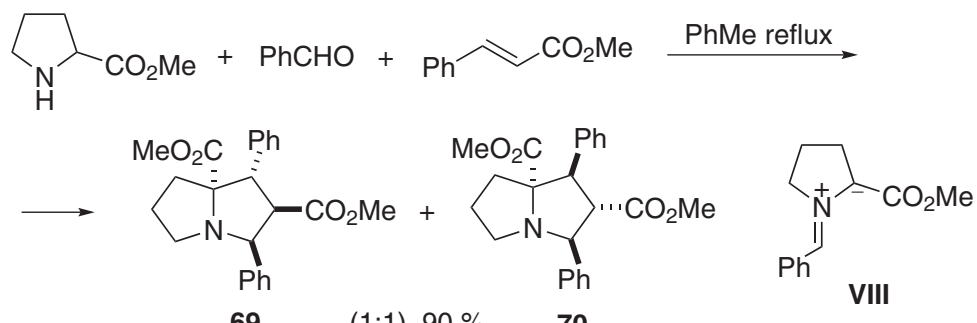

Scheme 10: Multicomponent 1,3-DC of methyl prolinate, benzaldehyde and methyl (E)-cinnamate.

The former process was performed by Maiti and co-workers [52] with cinnamaldehydes and different dipolarophiles, in dichloromethane at rt, providing pyrrolizidines $\mathbf{7 1}$ in high yields through an azomethine ylide of type VIII, by an endo approach (Fig. 5). When $\beta$-nitrostyrenes were used as dipolarophiles, compounds $\mathbf{7 2}$ were regio- and diastereoselectively formed according to an endo-approach and similar behavior was observed with acrylates and acrylonitrile leading to products 73 in good yields (Fig. 5). Independently, our group studied the same multicomponent 1,3-DC between methyl prolinate hydrochloride in the presence of $\mathrm{Et}_{3} \mathrm{~N}$, using toluene as solvent at $\mathrm{rt}$, different aldehydes and dipolarophiles [53]. This process can be performed alternatively in the presence of $\mathrm{AgOAc}(5 \mathrm{~mol} \%$ ) affording similar results. The presence of AgOAc was crucial when benzaldehyde and isopentanal were allowed to react with methyl acrylate as dipolarophile

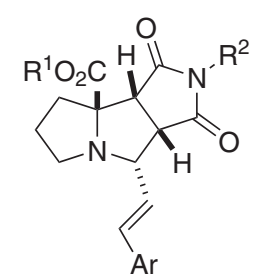

71 ${ }^{[47]}, 84-92 \%$

$\mathrm{R}^{1}=\mathrm{Me}, \mathrm{Et}, \mathrm{IPr}, \mathrm{Bn}$

$\mathrm{R}^{2}=\mathrm{Me}, \mathrm{Bn}, \mathrm{Ph}$

$\mathrm{Ar}=\mathrm{Ph}, 2-\mathrm{MeOC}_{6} \mathrm{H}_{4}$, $4-\mathrm{O}_{2} \mathrm{NC}_{6} \mathrm{H}_{4}, \mathrm{O}_{0}^{\mathrm{O}} \mathrm{s}$.

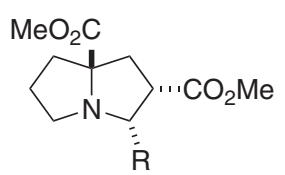

$74^{[48]}, 75-80 \%, 4: 1 \mathrm{dr}$

$$
\mathrm{R}=\mathbb{B u}, \mathrm{Ph}
$$

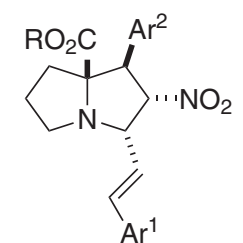

$$
72^{[48]}, 75-88 \%
$$

$\mathrm{R}=\mathrm{Me}, \mathrm{Et}$

$\mathrm{Ar}^{1} \mathrm{Ph}, 2-\mathrm{MeOC}_{6} \mathrm{H}_{4}$ $\mathrm{Ar}^{2}=4-\mathrm{ClC}_{6} \mathrm{H}_{4}, 4-\mathrm{MeC}_{6} \mathrm{H}_{4}$,

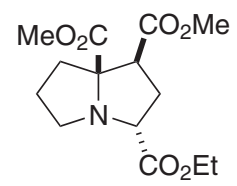

$75^{[48]}, 59 \%$

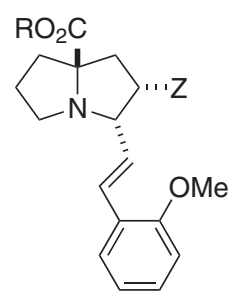

$73^{[48]}, 80-84 \%$

$\mathrm{R}=\mathrm{Me}, \mathbb{P r}, \mathrm{Bn}$

$\mathrm{Z}=\mathrm{CO}_{2} \mathrm{Me}, \mathrm{CN}$,

$\mathrm{CO}_{2} \mathrm{Et}$<smiles>[X]C(=O)CC1=[N+](C(OC)C(C)=O)CCC1</smiles>

Fig. 5: Pyrrolizidines from alkyl prolinates, aldehydes and dipolarophiles. 
giving mainly products 74 with up to 99:1 dr (Fig. 5). However, when ethyl glyoxylate was used as aldehyde the reaction only occurred in the presence of AgOAc affording exclusively the other regioisomer $\mathbf{7 5}$ as the only diastereomer. The formation of $\mathbf{7 5}$ can be explained by the participation of the azomethine ylide $\mathbf{I X}$, which reacted by the less substituted $\gamma$-position (Fig. 5).

Methyl (4S)-4-hydroxyprolinate gave mainly the corresponding enantiomerically pure adducts $\mathbf{7 6}$ when cinnamaldehyde and acrylates were used working under refluxing toluene (Scheme 11) [48].

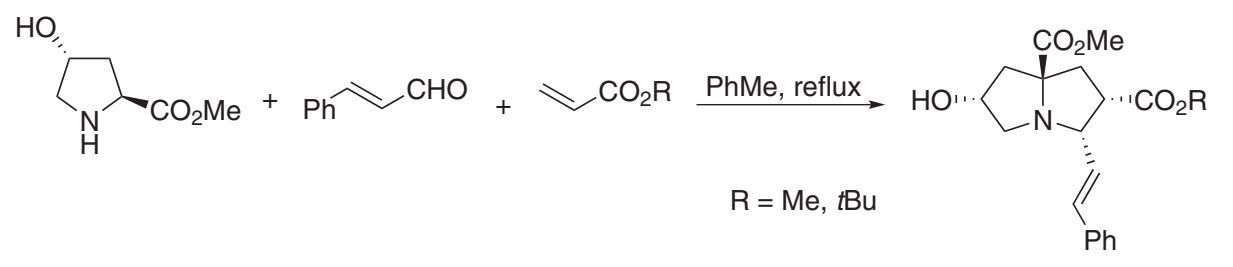

76, $82-85 \%(74-96 \%$ de)

Scheme 11: Three-component 1,3-DC of methyl (4S)-4-hydroxyprolinate with cinnamaldehyde and acrylates.

However, working in the presence, or in the absence of AgOAc, and $N$-methylmaleimide as dipolarophile, a 3:1 mixture of diastereomeric adducts 77 and 78 were obtained [54] (Fig. 6). Further studies about these processes, performed by our group with methyl (4S)-4-hydroxyprolinate, benzaldehyde and tert-butyl acrylate indicated that only compound 79 was isolated in the absence of AgOAc in $75 \%$ yield. In the case of using (E)-1,2-bis(phenylsulfonyl)ethylene, also the corresponding endo-pyrrolizidine $\mathbf{8 0}$ was exclusively obtained (Fig. 6) [54]. When $N$-crotonoyloxazolidinone was used as dipolarophile with methyl (4S)-4-hydroxyprolinate and cinnamaldehyde product $\mathbf{8 1}$ was obtained in $90 \%$ de (Fig. 6). From DFT calculations it can be deduced that the equilibrium between S-shape $\mathbf{X}$ and U-shape $\mathbf{X I}$ dipoles, derived from methyl prolinate and methyl (4S)-4-hydroxyprolinate and cinnamaldehyde, requires an activation barrier higher than $30 \mathrm{Kcal} \cdot \mathrm{mol}-{ }^{1}$ (Fig. 6). On the other hand, the high observed diastereoselection with the methyl (4S)-4-hydroxyprolinate derivative is a consequence of the presence of a hydrogen bonding during the endo-approach.

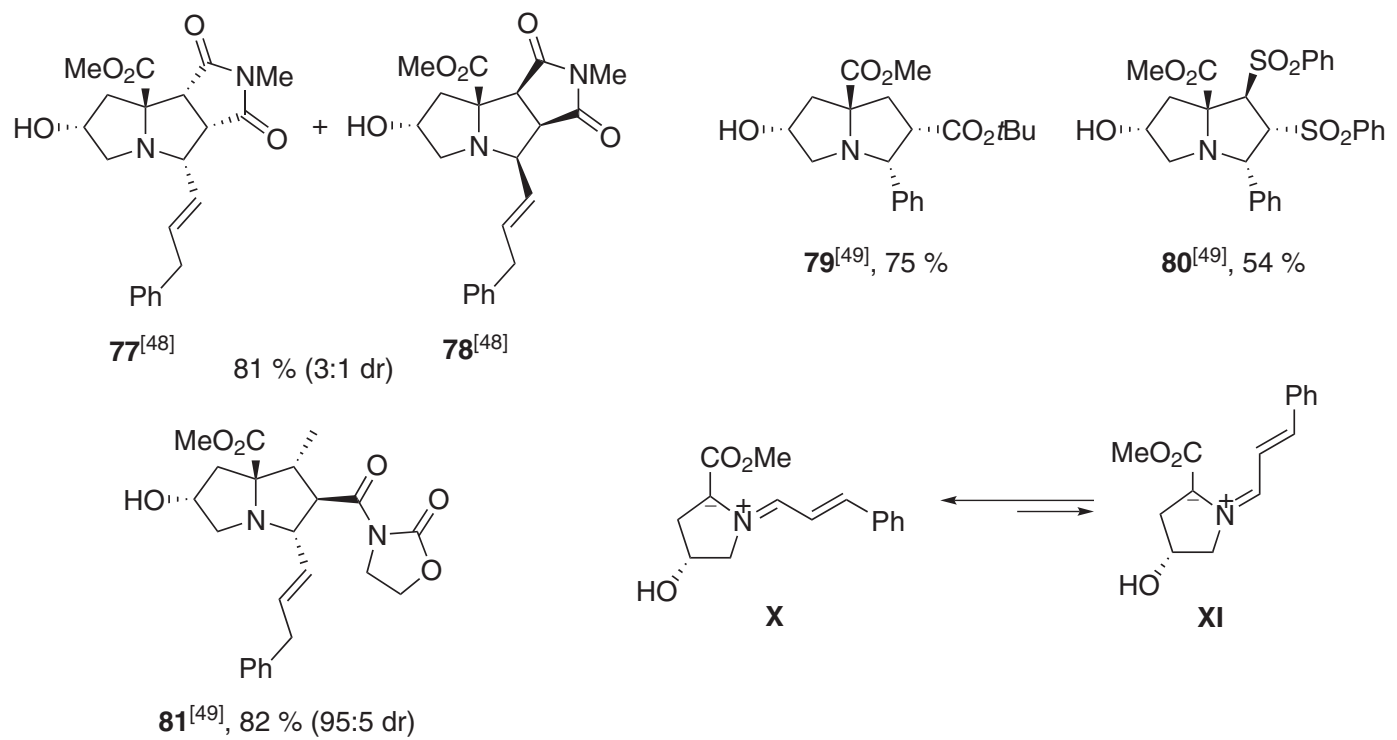

Fig. 6: Pyrrolizidines from methyl (4S)-4-hydroxyprolinate, aldehydes and dipolarophiles.

Consecutive three-component 1,3-DC were described by Shi and co-workers [55]. The initial multicomponent 1,3-DC was performed with glycine methyl ester, cinnamaldehyde and $N$-phenylmaleimide (NPM) giving racemic compound $\mathbf{8 2}$ in $73 \%$ yield (Scheme 12). Further treatment of these adducts $\mathbf{8 2}$ with the same 


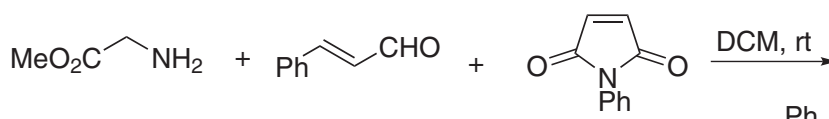<smiles>COC(=O)C1NC(/C=C/c2ccccc2)C2C(=O)N(c3ccccc3)C(=O)C12</smiles>

$83,59 \%$

Scheme 12: Consecutive multicomponent 1,3-DC.

reagents, under solvent-free conditions and heated with MW (700 W) for $10 \mathrm{~min}$, afforded the tetracyclic product 83 in $59 \%$ yield.

The same double 1,3-DC was performed by Zhang and co-workers in a single operation just under MW heating at $180^{\circ} \mathrm{C}$ in toluene (Scheme 13) [56]. Different aldehydes and maleimides have been used giving products $\mathbf{8 4}$ in good yields. When the former process was performed stepwise, it means first the formation of compound $\mathbf{8 2}\left(\mathrm{R}^{2}=\mathrm{Et}\right)$ and then different aldehydes and maleimides were added to the reaction media, the corresponding unsymmetrical tetracyclic compounds 85 were formed (Scheme 13).

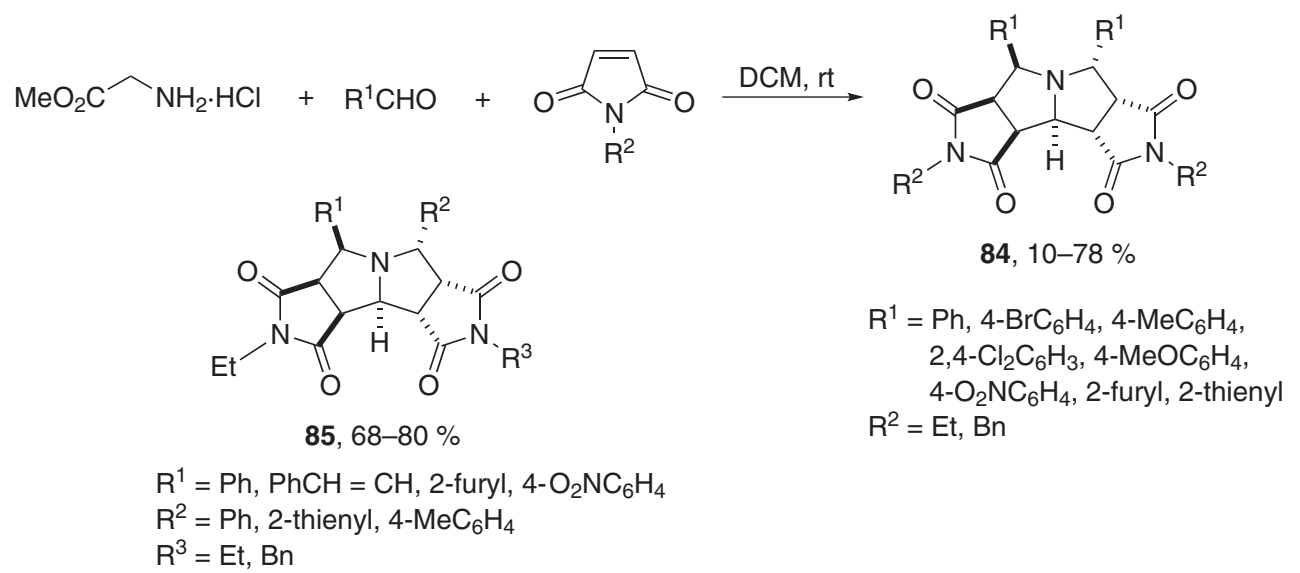

Scheme 13: Three-component 1,3-DC of methyl glycinate, aldehydes and maleimides.

Reisman and co-workers [57] performed this double 1,3-DC, first by synthesizing prolines 87 in 44-96\% ee using Schreiber's conditions [58]. The 1,3-DC of glycine imino with tert-butyl acrylate using QUINAP (86) and AgOAc, as catalyst, provided prolinates 87 with ee up to $96 \%$. Without isolation of adducts 87 , cinnamaldehyde and tert-butyl acrylate were added to the reaction media at rt providing pyrrolizidines $\mathbf{8 8}$, with the same ee that for $\mathbf{8 7}$ by intermediacy of the azomethine ylide XII (Scheme 14).

Our group has performed a double 1,3-DC using enantioenriched nitro prolinates 90 [59]. The first 1,3-DC was carried out with glycine imino esters and nitroalkenes using chiral phosphoramidite 89 and $\mathrm{Cu}(\mathrm{OTf})_{2}$ [60], AgOTf, or $\mathrm{AgO}_{2} \mathrm{CPh}$ [42] complexes providing exo-4-nitroprolinates 90 [47, 60, 61]. Representative exo-90 $\left(\mathrm{R}^{1}=\mathrm{R}^{2}=\mathrm{Ph},>99 \%\right.$ ee) was allowed to react in a multicomponent 1,3-DC with cinnamaldehyde and different dipolarophiles under AgOAc catalysis in NMP at $70^{\circ} \mathrm{C}$ affording pyrrolizidines endo- and exo-91 in moderate to high diastereoselectivity by means of the azomethine ylide XIII, which reacts with dipolarophiles mainly through an endo-approach (Scheme 15 and Fig. 7) [59].

In the case of $N$-methylmaleimide or maleimide, the diastereomeric products 91a and 91b were obtained in 2:1 dr, which could be separated by flash chromatography. However, in the case of $\mathrm{N}$-phenylmaleimide exo91c was mainly obtained in a 3:1 dr which, after chromatographic separation, gave the exo-diastereomer in 
<smiles>[R]C=NCC(C)=O</smiles>

$t \mathrm{BuO}_{2} \mathrm{C}$<smiles>[R7]C1CCC(C(C)=O)N1</smiles>

$87,44-96 \%$<smiles>CCOC(=O)C=CC=Cc1ccccc1</smiles>

THF, $23^{\circ} \mathrm{C}, 1$ day

$t \mathrm{BuO}_{2} \mathrm{C}$<smiles>CCC1CCC(C(C)=O)/[N+]1=C/C=C/c1ccccc1</smiles>

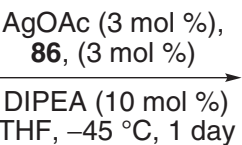<smiles>[R]C1[C@H](C(=O)OCC(C)(C)C)C[C@@]2(C(C)=O)C[C@H](C(=O)OCC)[C@H](/C=C/c3ccccc3)N12</smiles>

88, 33-91\%, 44-96 \% ee

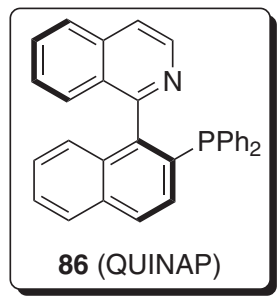

$\mathrm{R}=\mathrm{Ph}, 2-\mathrm{MeC}_{6} \mathrm{H}_{4}, 3-\mathrm{MeC}_{6} \mathrm{H}_{4}, 4-\mathrm{MeC}_{6} \mathrm{H}_{4}, 4-\mathrm{FC}_{6} \mathrm{H}_{4}$, 4- $\mathrm{ClC}_{6} \mathrm{H}_{4}, 4-\mathrm{BrC}_{6} \mathrm{H}_{4}, 4-\mathrm{O}_{2} \mathrm{NC}_{6} \mathrm{H}_{4}, 4-\mathrm{NCC}_{6} \mathrm{H}_{4}$, 4- $\mathrm{MeOC}_{6} \mathrm{H}_{4}, 2-\mathrm{MeOC}_{6} \mathrm{H}_{4}, 2-\mathrm{ClC}_{6} \mathrm{H}_{4}, 2-\mathrm{BrC}_{6} \mathrm{H}_{4}$, 3- $\mathrm{BrC}_{6} \mathrm{H}_{4}, 3,5-\mathrm{Me}_{2} \mathrm{C}_{6} \mathrm{H}_{3}, 1$-naphthyl, 2-naphthyl, 3-Py, 2-Py, styryl

Scheme 14: Double consecutive 1,3-DC.

$65 \%$ yield. Methyl acrylate gave regio- and diastereoselectively endo-91d in $92 \%$ de which, after purification, afforded the pure pyrrolizidine in $88 \%$ yield. Methyl fumarate gave a 2:1 mixture of endo and exo-91e which were separated after purification in 48 and $26 \%$ yield, respectively. When methyl or ethyl acetylenedicarboxylates were employed as dipolarophiles compounds $\mathbf{9 1 f}$ and $\mathbf{9 1 g}$ were obtained in moderate yields. The endo approach could be explained by means of model $\mathbf{A}$ in which the steric interactions between the two phenyl groups of the exo-nitroprolinate $\mathbf{9 0}$ were avoided. In the case of $N$-phenylmaleimide (NPM) the steric interactions between the phenyl group of NPM and the nitro group favors the exo-approach as indicated in model B. On the other hand, the stereochemistry observed with the methyl acrylate justified the $\alpha$-attack of the azomethine ylide XIII to the dipolarophile (Fig. 7).

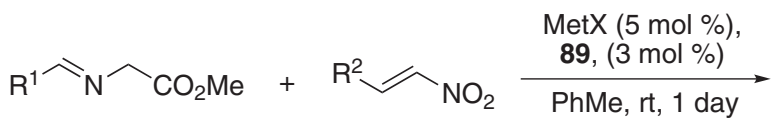

$\mathrm{MetX}=\mathrm{Cu}(\mathrm{OTf})_{2}, \mathrm{AgOTf}, \mathrm{AgO}_{2} \mathrm{CPh}$<smiles>[R7]C1N[C@H](C(=O)OC)[C@H]([N+](=O)[O-])[C@@H]1C</smiles>

$90,60-92 \%, 50-92 \%$ de, $84-99 \%$ ee

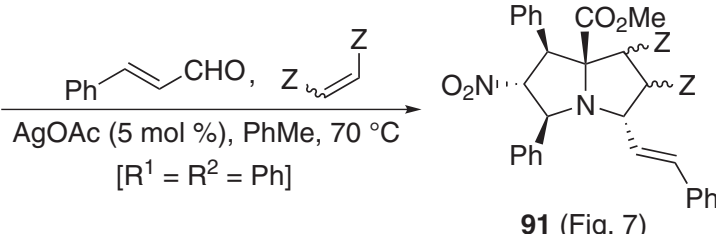

91 (Fig. 7)<smiles>COC(=O)C1=C(c2ccccc2)C([N+](=O)[O-])C(c2ccccc2)[N+]1=CC=Cc1ccccc1</smiles>

XIII

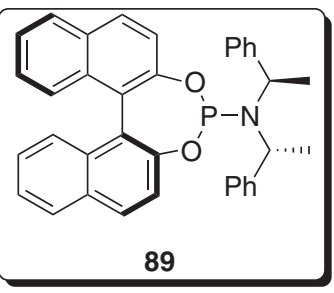

Scheme 15: Double stepwise 1,3-DC.

Sing and co-workers has recently performed a double consecutive 1,3-DC by synthesizing firstly prolinates 93 by enantiocatalyzed 1,3-DC of glycine imino esters with $\alpha, \beta$-unsaturated pyrazolamides using the chiral complex formed by (R)-DM-SEGPHOS (92) and AgOTf (Scheme 16) [62]. Afterwards, cinnamaldehydes and maleimides were added to the reaction flask providing pyrrolizidines 94 in moderate to high endo-diastereoselectivity. Further reduction of compound endo-94 with $\mathrm{NaBH}_{4}$ and $\mathrm{LiAlH}_{4}$ gave different hydroxylated pyrrolizidines. 
<smiles>COC(=O)[C@H]1[C@H]([N+](=O)[O-])[C@@H](c2ccccc2)N2[C@@H](/C=C/c3ccccc3)[C@@H]3C(=O)N(P)C(=O)[C@H]3[C@]12C</smiles>

endo-91a: $\mathrm{R}=\mathrm{Me}, 70 \%$ endo-91b: $\mathrm{R}=\mathrm{H}, 65 \%$<smiles>COC(=O)[C@@H]1[C@H](C(C)=O)[C@]2(C(C)=O)[C@@H](c3ccccc3)[C@H]([N+](=O)[O-])[C@@H](c3ccccc3)N2[C@@H]1/C=C/c1ccccc1</smiles>

endo-91e, $48 \%$

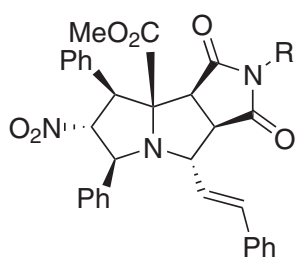

exo-91a: $\mathrm{R}=\mathrm{Me}, 26 \%$ exo-91b: $\mathrm{R}=\mathrm{H}, 30 \%$

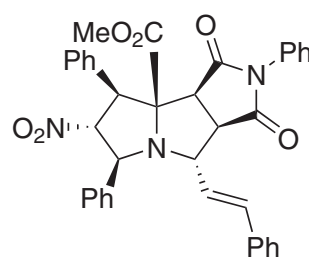

exo-91c, $65 \%$<smiles>COC(=O)[C@H]1C[C@@]2(C(=O)OC)[C@@H](c3ccccc3)[C@H]([N+](=O)[O-])C(c3ccccc3)N2[C@H]1/C=C/c1ccccc1</smiles>

endo-91d, $88 \%$<smiles>[R]OC(=O)C1=C(C(=O)O)[C@@]2(C(=O)O)[C@@H](c3ccccc3)C([N+](=O)[O-])[C@H](c3ccccc3)N12</smiles>

91f: $R=M e, 31 \%$ 91g: $R=E t, 35 \%$

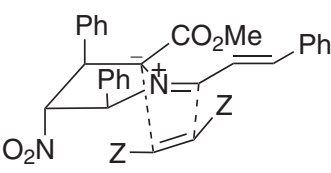

A

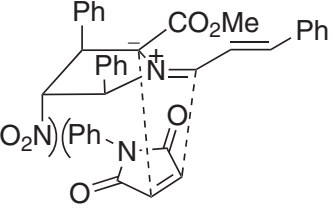

B

Fig. 7: Pyrrolizidines from exo-nitroprolinate $90\left(R^{1}=R^{2}=P h\right)$, cinnamaldehyde and dipolarophiles.

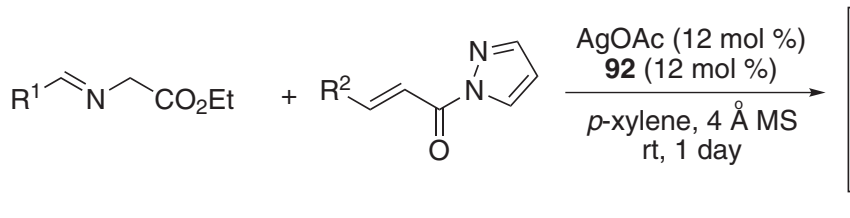<smiles>[R7]C1[C@H](C(=O)OCC)N[C@H](CC)[C@@H]1C(=O)n1cccn1</smiles><smiles>[R9]C=CC1C(=O)N([Z7])C(=O)[C@H]2[C@H](/C=C/[R])N([R])[C@H](C(=O)n3cccn3)[C@]12C</smiles>

Endo-94, 58-70\%, 56-84\% de, $90-98 \%$ ee
93<smiles>CCCCc1ccc2c3c1CCCC3CCO2</smiles>

Scheme 16: Double consecutive 1,3-DC.

A different multicomponent 1,3-DC has been performed by Coldham and co-workers using the aldehyde 95, glycine ethyl ester hydrochloride and dipolarophiles (Scheme 17) [63]. This process afforded pyrrolizidines 96 under refluxing toluene with good diastereoselectivity in favor of the endo-cycloadducts.

\section{Multicomponent synthesis of indolizidines by decarboxylative 1,3-DC}

The decarboxylative route to azomethine ylides from primary and secondary $\alpha$-amino acids was first described by Grigg and co-workers [7-12]. Starting from tetrahydrosioquinoline-3-carboxylic acid 98a and aldehydes and $N$-methylmaleimide in DMF at $120^{\circ} \mathrm{C}$, the corresponding cycloadducts 99 were obtained as ca. 1:1 mixture of endo and exo-benzoindolizidines 99 derived from the syn-dipole XIV (Scheme 18). This process has been studied with tetrahydro- $\beta$-carboline-3-carboxylic acid giving a 1:1 mixture of endo/exoproducts 100. In the case of pipecolinic acid the corresponding indolizidine 101 was formed by reaction 
<smiles>CCOC(=O)[C@@H]1C2C(=O)N(C)C(=O)C2C2N1CCC2(C)C</smiles>

$97 a, 73 \%, 70 \%$ de

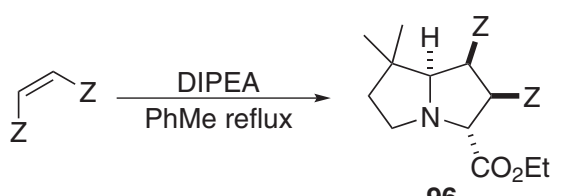

96

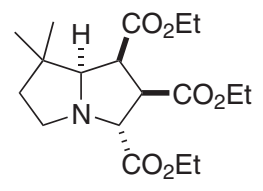

$97 b, 52 \%, 83 \%$ de

Scheme 17: Three-component 1,3-DC of chloro aldehyde 95 with ethyl glycinate and dipolarophiles.

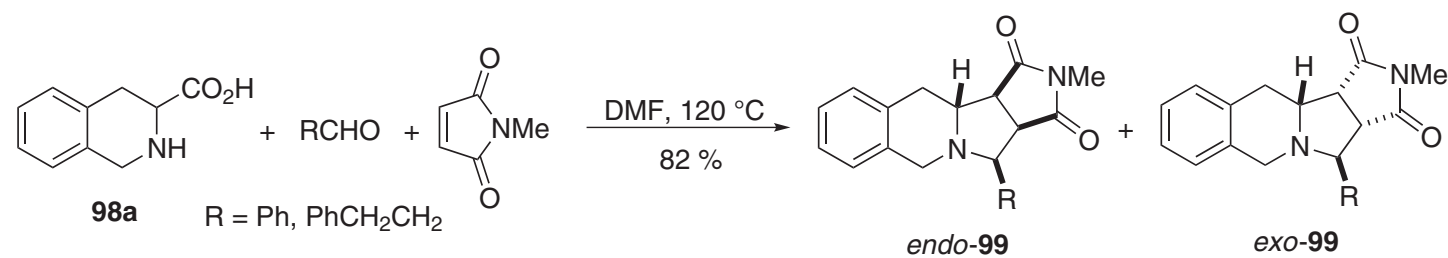<smiles>O=C1C2[C@@H]3Cc4c([nH]c5ccccc45)CN3C[C@@H]2C(=O)N1O</smiles>

100

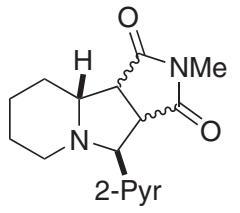

101<smiles>[R]C=[N+]1CCc2ccccc2C1</smiles>

syn-XIV

Scheme 18: Three-component 1,3-DC of tetrahydroisoquinoline-3-carboxylic acid, aldehydes and maleimides.

with 2-pyridinecarboxaldehyde and $N$-methylmaleimide (NMM) in $70 \%$ yield. However, in the case of tetrahydroisoquinoline- and tetrahydro- $\beta$-carboline-1-carboxylic acid the reaction with benzaldehyde and NMM gave, through syn and anti-dipoles, mixtures of the four diastereomers.

Grigg and co-workers also demonstrated that, in the case of cyclic $\alpha$-amino acids intermediate oxazolidine-5-ones, 1,4-prototropic rearrangement of the azomethine ylide or formation of a stable azomethine ylide can occur during the decarboxylative 1,3-DC [10, 64].

Banerjee and co-workers studied the reaction of pipecolinic acid with isatin and a carbohydrate olefin (Scheme 3) [17]. In the case of pipecolinic acid the spiro compound was formed under refluxing toluene (Scheme 19).

Other examples using isatins, already described in the case of pyrrolizidines, are compiled in Fig. 8 using pipecolic acid. In these cases, compound 103 has been isolated by a three-component 1,3-DC using an unsaturated carbohydrate lactone as dipolarophile [24]. Another example is the synthesis of spiro indolizidines 104 from nitro chromans 22 [25]. In the reaction of tetraethyl vinylidenebis(phosphonate) (38) [25] the<smiles>CC(=O)C1=C[C@H]2OC(C)(C)O[C@@H]2OC1C(=O)O</smiles><smiles></smiles>

$102,70 \%$

Scheme 19: Three-component 1,3-DC of pipecolinic acid, isatin and a carbohydrate-derived dipolarophile. 
<smiles>C=CCO[C@H]1C=CC(=O)O[C@H]1OC(C)=O</smiles><smiles>[R]C1Oc2ccccc2[C@@]2(c3ccccc3NC(=O)[C@@]23N([O-])C2CCCCN23)[C@H]1O</smiles><smiles>[R]c1ccc2c(c1)NC(=O)C21CC([R]OCC)(POCC)C2CCCCN21</smiles>

$105^{[33]}, 35-65 \%$<smiles>C=C[C@H]1CN2CC[C@@]3(OC2C1C[C@H]1NCCc2c1[nH]c1ccccc21)C(=O)Nc1cc(O)ccc13</smiles>

106 (strychnofoline)

Fig. 8: Spirooxindole-indolizidines.

corresponding indolizidines 105 were prepared in acetonitrile at $80^{\circ} \mathrm{C}$ in moderate yields. This spiro indoleindolizidine unit is present in the natural product strychnofoline 106.

Our group has studied the multicomponent decarboxylative 1,3-DC of pipecolinic acid with cinnamaldehyde or benzaldehyde with different dipolarophiles providing indolizidines 107 (Scheme 20) [65]. The process took place in refluxing toluene giving mixtures of the four diastereomers due to the participation of anti- and syn-XVII azomethine ylides. In the case of NMM or NPM products 107a-c were formed whereas

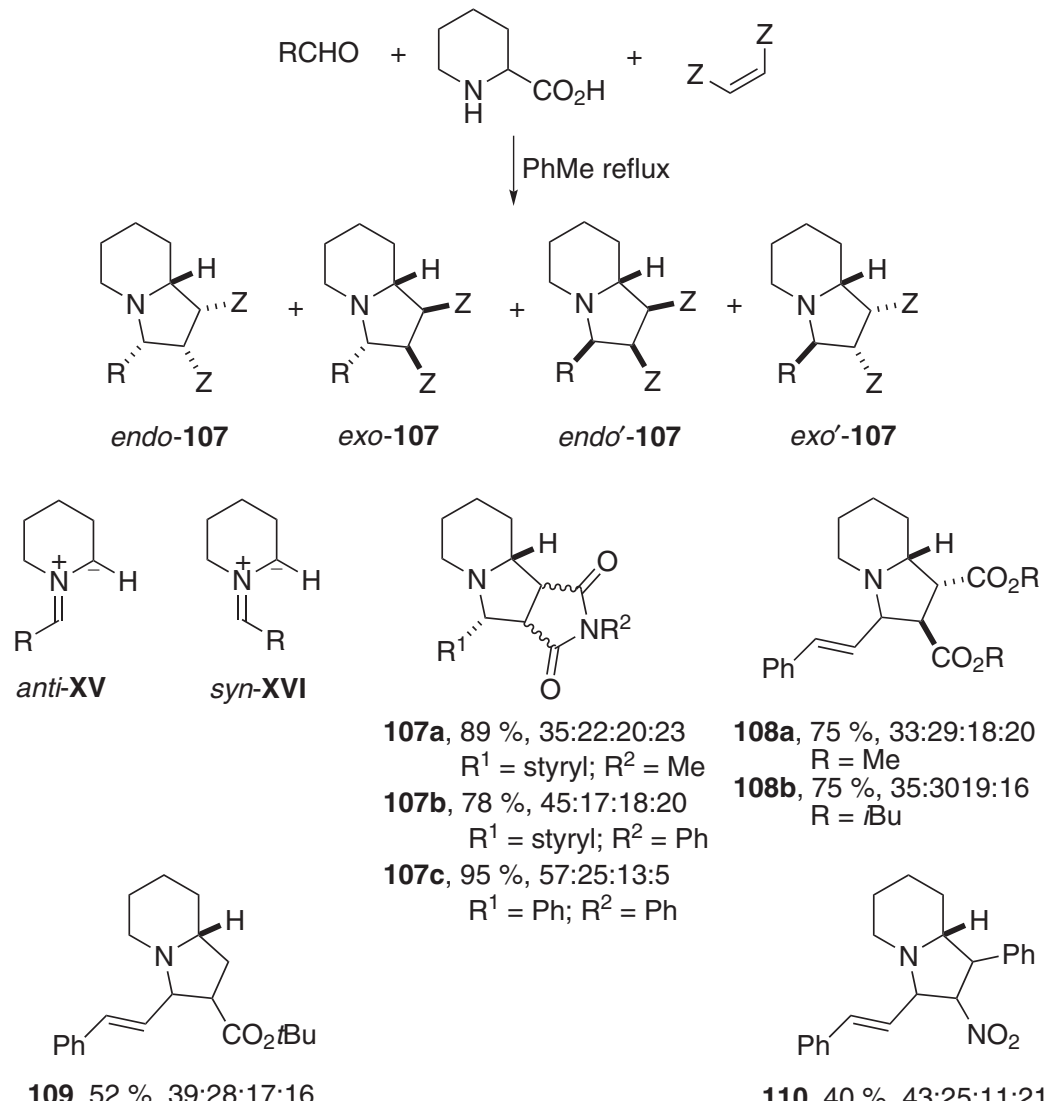

Scheme 20: Three-component 1,3-DC of pipecolic acid, aldehydes and dipolarophiles. 


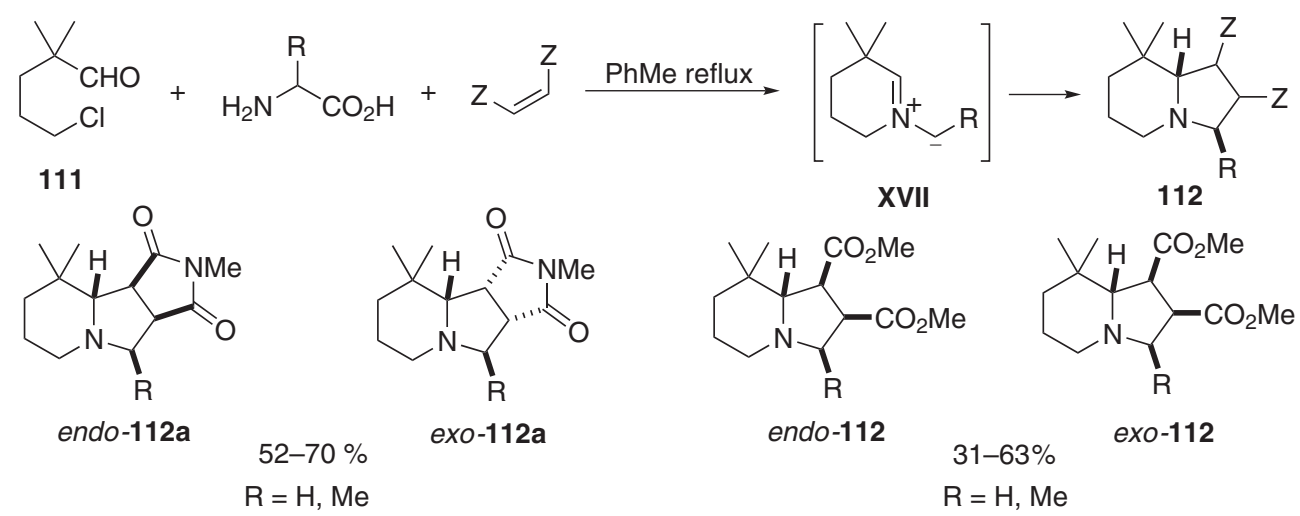

Scheme 21: Three-component 1,3-DC of aldehyde 111 with $\alpha$-amino acids and dipolarophiles.

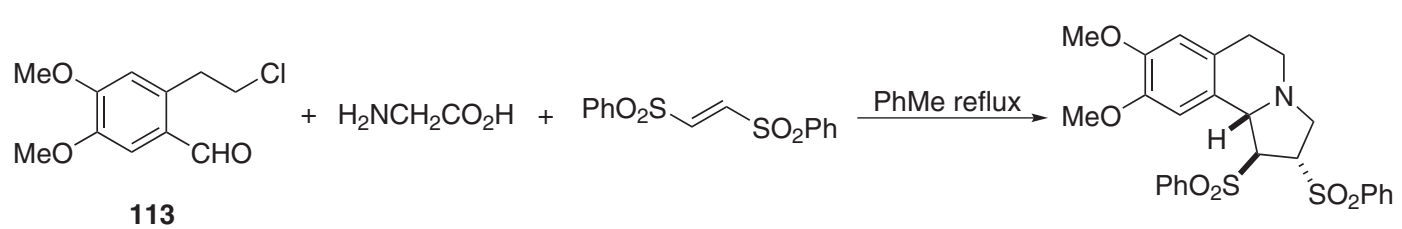

$114,70 \%$

Scheme 22: Three-component 1,3-DC of glycine, the aldehyde 113 and (E)-bis(phenylsulfonyl)ethylene.

dimethyl and diisobutyl fumarates afforded indolizidines 108a-b. In the example of tert-butyl acrylate only regioisomeric products 109, resulted from the $\alpha$-attack of azomethine ylides XV and XVI, were isolated. The same happened with $\beta$-nitrostyrene, providing the nitroindolizidines $\mathbf{1 1 0 .}$

Coldham and co-workers have used 111, the homologous aldehyde of 95 (Scheme 17), in the three-component decarboxylative 1,3-DC with $\alpha$-amino acids and dipolarophiles, affording 1:1 mixtures of endo:exo indolizidines 112 under refluxing toluene, by intermediacy of the azomethine ylide XVII (Scheme 21) [63, 66].

The former process has been performed with different halogen substituted aldehydes. In the case of ortho2-(bromoethyl)benzaldehyde 113, the precursor 114 of crispine was prepared in $70 \%$ yield (Scheme 22) [66].

\section{Multicomponent synthesis of indolizidines by 1,3-DC}

Joucla and co-workers reported the multicomponent 1,3-DC of ethyl pipecolinate with benzaldehyde and NMM giving a 3:1 mixture of endo/exo indolizidines 115a (Scheme 23) [51]. However, in the case of methyl fumarate a 1:1 mixture of endo/exo 115b was obtained. The diastereomeric result was explained by the participation of the azomethine ylide XVIII.

As in the case of alkyl prolinates, Grigg and co-workers described the three-component 1,3-DC of methyl tetrahydroisoquinoline-3-carboxylate (98b) with (+)-menthyl glyoxylate (116) and NMM [67]. This 1,3-DC took place in DMF at $110^{\circ} \mathrm{C}$ providing a 5:1 mixture of endo/exo cycloadducts 117 in $73 \%$ yield arising from the azomethine ylide XIX (Scheme 24). Methyl tetrahydro- $\beta$-carboline-3-carboxylate gave a 3.5:1 mixture of isomeric cycloadducts, compound 118 being isolated in $51 \%$ yield. However, when 2-methoxybenzaldehyde was allowed to react with methyl tetrahydroisoquinoline-3-carboxylate a ca. 1:1 mixture of separable products 119 were obtained by the formation of the azomethine ylide $\mathbf{X X}$.

Our group has described the three-component 1,3-DC of methyl pipecolinate hydrochloride with cinnamaldehyde and dipolarophiles, in toluene at $75^{\circ} \mathrm{C}$, affording indolizidines 120-127 as mixture of diastereomers (Scheme 25) [65]. In the case of methyl acrylate, endo-120 was isolated in agreement with the $\alpha$-attack of azomethine ylide XXI. Methyl fumarate gave a separable mixture of endo/exo-adducts $\mathbf{1 2 1}$ in 70 and $11 \%$ 


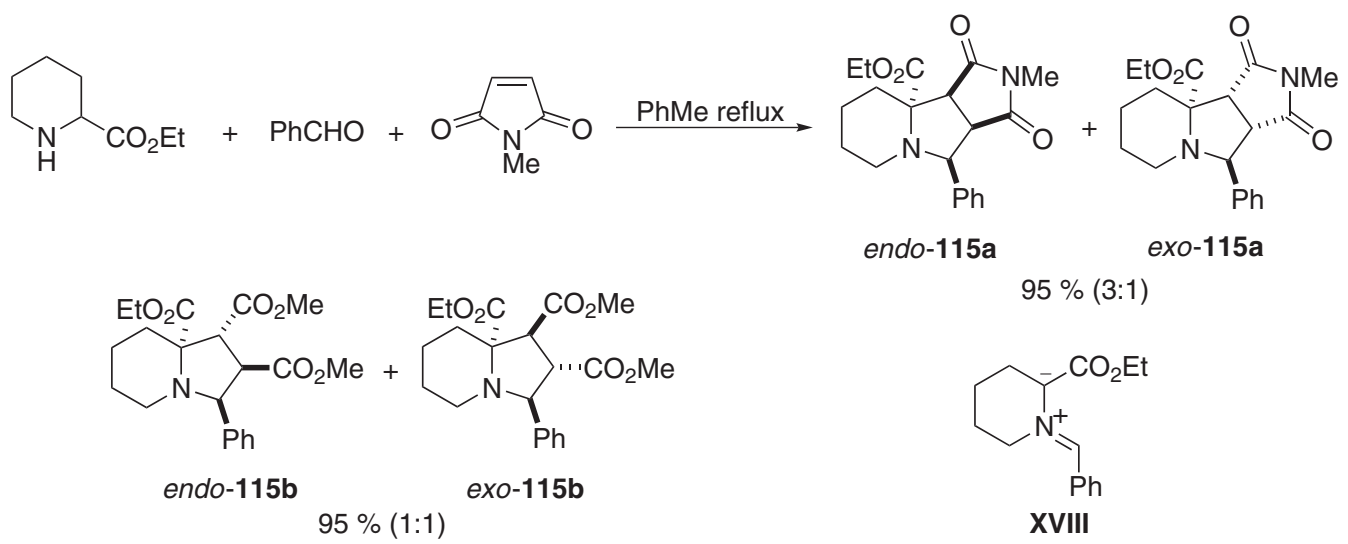

Scheme 23: Three-component 1,3-DC of ethyl prolinate, benzaldehyde and dipolarophiles.

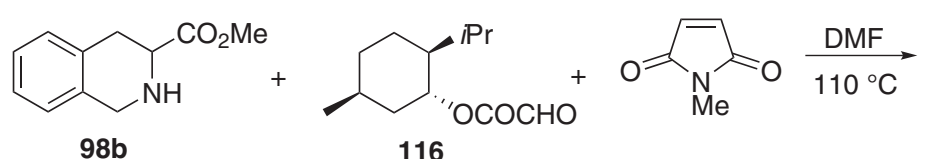<smiles>COC(=O)OC1[C@H]2C(=O)NC(=O)[C@@H]2[C@@H]2c3ccccc3C[C@H](C(C)=O)N12</smiles>

endo-117

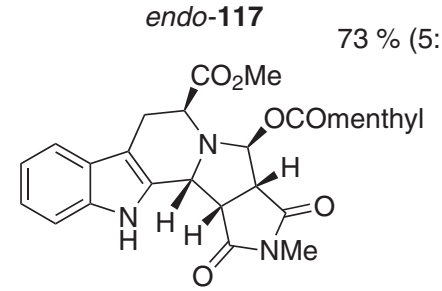

$118,51 \%$<smiles>CC(=O)OC1[C@H]2C(=O)N(C)C(=O)[C@@H]2[C@@H]2c3ccccc3C[C@H](C(C)=O)N12</smiles>

exo-117<smiles></smiles>

XIX

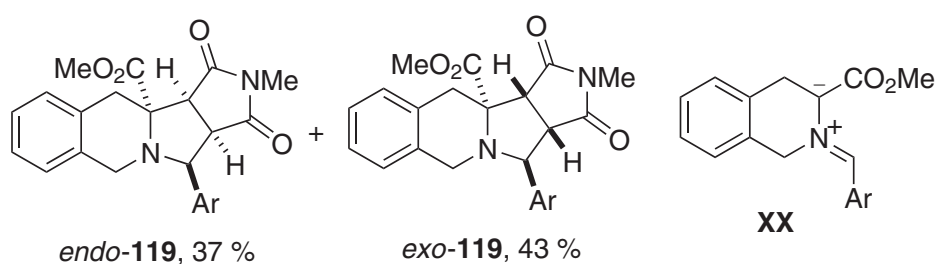

Scheme 24: Three-component 1,3-DC of methyl tetrahydroisoquinoline-3-carboxylate and methyl tetrahydro- $\beta$-carboline-3carboxylate 98b with (+)-menthyl glyoxylate 116 and dipolarophiles.

yield, respectively. However, chalcone afforded regioselectively exo-122. When $\beta$-nitro styrene was used as dipolarophile a 1:3 mixture of regioisomeric endo-123 and exo-124 was obtained. $N$-Methyl and $N$-phenylmaleimide gave a 7:3 mixture of products endo/exo 125. When benzaldehyde was used as carbonyl component and maleic anhydride as dipolarophile, compound endo-126 was obtained in modest yield with total diastereoselectivity. In the case of the reactions performed with furfural and NMM, products endo/exo 127 were isolated with $64 \%$ de. The major endo-products could be isolated and in the case of endo-127 the relative configuration was assigned according to X-ray diffraction analysis.

The multicomponent 1,3-DC of 1,2-diaza-1,3-diene $\mathbf{1 2 8}$ with formaldehyde and ethyl pipecolate gave regioselectively indolizidine derivatives 129 in moderate yield (Scheme 26) [68]. 


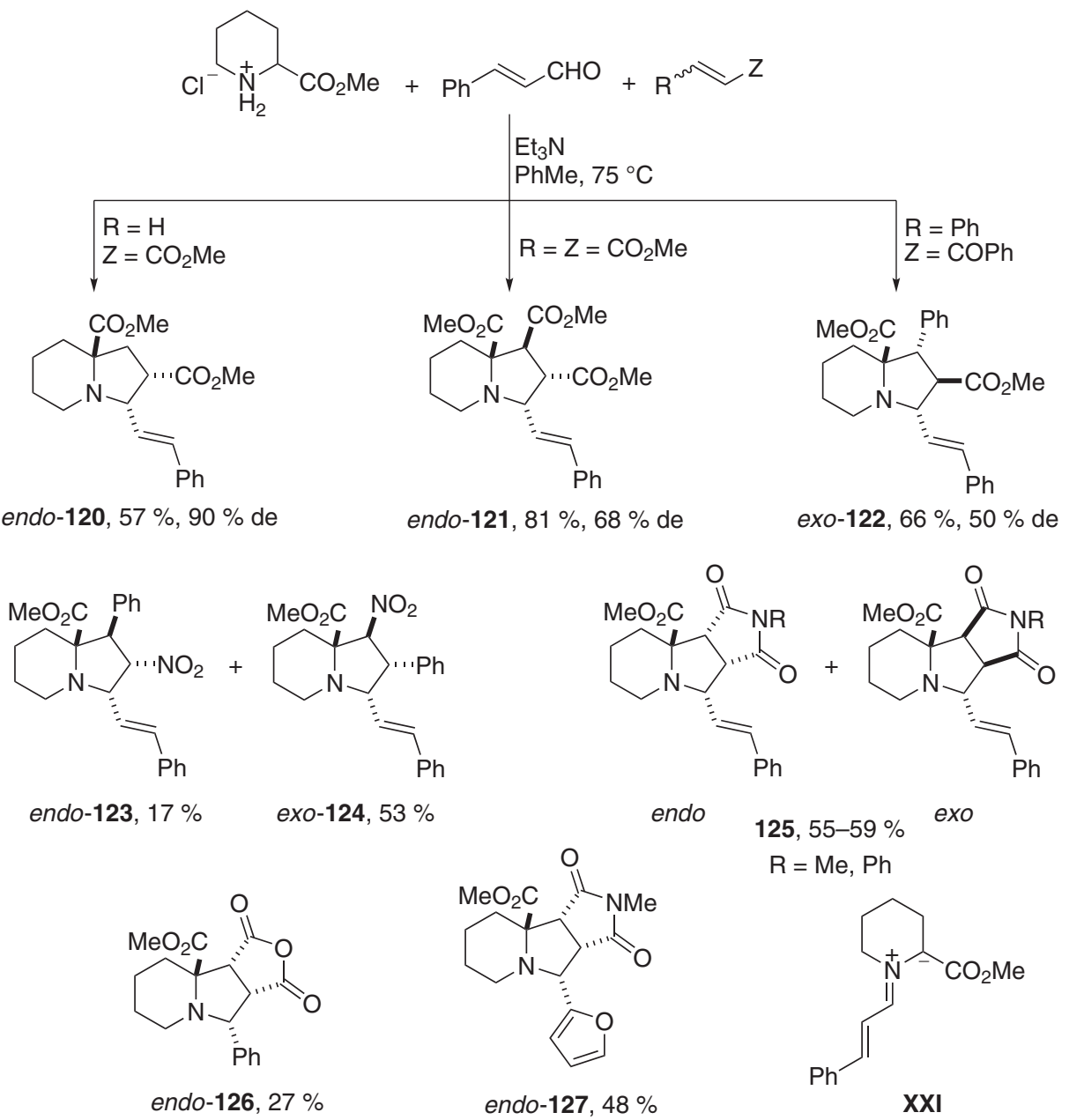

Scheme 25: Three-component 1,3-DC of methyl pipecolate with cinnamaldehyde and dipolarophiles.

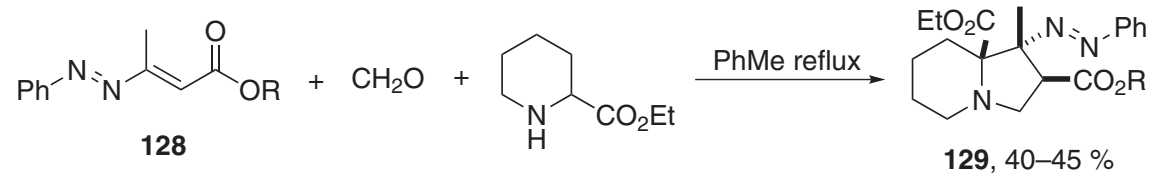

$\mathrm{R}=\mathrm{Me}, \mathrm{Et}$

Scheme 26: Three-component 1,3-DC of ethyl pipecolate, compounds 128 and formaldehyde.

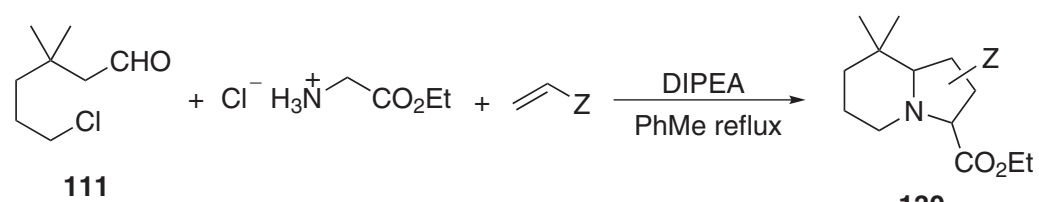<smiles>CCOC(=O)[C@@H]1[C@@H]2C(=O)N(C)C(=O)[C@@H]2[C@H]2N1CCCC2(C)C</smiles>

$130 a$<smiles>CCOC(=O)[C@H]1[C@@H](COC)[C@H](C(C)=O)[C@H]2N1CCCC2(C)C</smiles>

$130 b$<smiles>CCOC(=O)[C@@H]1CC(C(=O)OC)C[C@@H]2C(C)CCCN12</smiles>

$130 c$

Scheme 27: Three-component 1,3-DC of ethyl glycinate, the aldehyde 111 and dipolarophiles. 
Coldham and co-workers have described the three-component 1,3-DC of the $\gamma$-chloro aldehyde 95 for the synthesis of pyrrolizidines (Scheme 17) [63]. When the homologous aldehyde $\mathbf{1 1 1}$ was allowed to react with ethyl glycinate hydrochloride and different dipolarophiles, indolizidines 130 were prepared (Scheme 27) [66]. In the case of NMM and methyl maleate, a mixture of three separable diastereomers in ca. 2:2:1 and 94 and $74 \%$ yield were obtained, respectively, diasteromers $130 \mathrm{a}$ and $130 \mathrm{~b}$ being mainly identified. For methyl acrylate, a 3.4:2.4 mixture of the corresponding regioisomers 130c was obtained in $77 \%$ overall yield.

\section{Conclusions}

Three-components 1,3-dipolar cycloadditions between cyclic $\alpha$-amino acids, carbonyl compounds and electrophilic alkenes are an excellent, simple and powerful methodology for the thermal synthesis of the pyrrolizidine and indolizidine derivatives. The atom economy of these processes is total except for the reactions involving decarboxylations where a small molecule of carbon dioxide is lost. By means of proline and pipecolinic acid or related amino acids the intermediate azomethine ylides are formed by condensation with the carbonyl compound via a decarboxylative process. This metododology allows the synthesis of spiro-pyrrolizidines and -indolizidines when ketones are used as carbonyl component with high regio- and diastereocontrol. In particular, the synthesis of biological active spirooxindole-pyrrolizidines can be carried out using isatins as carbonyl components in only one step operation. The regio- and diastereoselectivity can be better controlled in the case of using cyclic $\alpha$-amino acid derived esters than in the decarboxylative 1,3-DC giving the corresponding pyrrolizidines and indolizidines with an alkoxycarbonyl substituent in the bridge of the bicyclic systems. The last methodology can be also performed using a double 1,3-DC, first the asymmetric synthesis of the proline unit followed by the three-component 1,3-DC affording enantioenriched pyrrolizidines.

Acknowledgements: We gratefully acknowledge financial support from the Spanish Ministerio de Economía y Competitividad (MINECO) (projects CTQ2013-43446-P and CTQ2014-51912-REDC), the Spanish Ministerio de Economía, Industria y Competitividad, Agencia Estatal de Investigación (AEI) and Fondo Europeo de Desarrollo Regional (FEDER, EU) (projects CTQ2016-76782-P and CTQ2016-81797-REDC), the Generalitat Valenciana (PROMETEOII/2014/017) and the University of Alicante. We warmly thank to all our co-workers for their generous work and effort to perform this research and to Prof. Miguel Yus for his help in the ellaboration of this manuscript

Article note: A special collection of invited papers by recipients of the IUPAC Distinguished Women in Chemistry and Chemical Engineering Awards.

\section{References}

[1] C. Bhat, S. G. Tilve. RSC Adv. 4, 5405 (2014).

[2] N. Asano, R. J. Nash, R. J. Mdyneux, G. W. J. Fleet. Tetrahedron: Asymmetry 11, 1645 (2000).

[3] T. Hashimoto, K. Maruoka. Chem. Rev. 115, 5366 (2015).

[4] M. S. Sing, S. Chowdhury, S. Koley. Tetrahedron 72, 1603 (2016).

[5] B. Bdiri, B.-J. Zhao, Z.-M. Zhou. Tetrahedron: Asymmetry 28, 876 (2017).

[6] H. D. Döndas, M. de G. Retamosa, J. M. Sansano. Synthesis 49, 2819 (2017).

[7] R. Grigg, S. Surendrakumar, S. Thianpatanagui, D. Vipond. J. Chem. Soc. Chem. Commun. 47 (1987).

[8] R. Grigg, J. Idle, P. McMeekin, D. Vipond. J. Chem. Soc. Chem. Commun. 49 (1987).

[9] R. Grigg, S. Surendrakumar, S. Thianpatanagui, D. Vipond. J. Chem. Soc. Perkin Trans. 1, 2693 (1988).

[10] R. Grigg, J. Idle, P. McMeekin, S. Surendrakumar, D. Vipond. J. Chem. Soc. Perkin Trans. 1, 2703 (1988).

[11] F. Orsini, F. Pelizzoni, M. Forte, M. Sisti, F. Merati, P. Gariboldi. J. Heterocyclic Chem. 25, 1605 (1988).

[12] R. Grigg, M. F. Jones, M. McTiernan, V. Sridharan. Tetrahedron 57, 7979 (2001).

[13] J. Azizian, A. R. Karimi, A. A. Mohammadi, M. R. Mohammadizadeh. Synthesis 2263 (2004). 
[14] A. R. S. Babu, R. Raghunathan. Tetrahedron Lett. 47, 9221 (2006).

[15] R. D. R. S. Manian, J. Jayashankaran, R. Raghunathan. Tetrahedron 62, 12357 (2006).

[16] N. V. Lakshmi, P. Thirumurugan, C. Jayakumar, P. T. Perumal. Synlett 955 (2010).

[17] P. D. Barman, I. Sanyal, S. B. Mandal, A. K. Banerjee. Synthesis 3563 (2011).

[18] R. R. Kumar, S. Perumal, P. Senthilkumar, P. Yogeeswari, D. Sriram. Tetrahedron 64, 2962 (2008).

[19] A. R. S. Babu, R. Raghunathan. Tetrahedron Lett. 48, 305 (2007).

[20] G. Chen, J. Zhang, V. Wu. Res. Chem. Intermed. 38, 413 (2012).

[21] V. Y. Korotaev, I. B. Kutyashev, A. Y. Barkov, V. Y. Sosnovskikh. Chem. Heterocyclic Comp. 53, 1192 (2017).

[22] J. Jayashankaran, R. D. R. S. Manian, R. Raghunathan. Tetrahedron Lett. 45, 7303 (2004).

[23] A. R. S. Babu, R. Raghunathan. Tetrahedron Lett. 48, 6809 (2007).

[24] J. N. S. Rao, R. Raghunathan. Tetrahedron Lett. 53, 854 (2012).

[25] J. N. S. Rao, R. Raghunathan. Tetrahedron Lett. 56, 2276 (2015).

[26] V. Rajkumar, N. A. Aslam, C. Reddy, S. A. Babu. Synlett 23, 549 (2012).

[27] M. Bakthadoss, D. Kannan, G. Sivakumar. Synthesis 44, 793 (2012).

[28] J.-A. Xiao, H.-G. Zhang, S. Liang, J.-W. Ren, H. Yang, X.-Q. Chen. J. Org. Chem. 78, 1157 (2013).

[29] C. E. Puerto Galvis, V. V. Kouznetsov. Org. Biomol. Chem. 11, 7372 (2013).

[30] G. Wu, L. Ouyang, J. Liu, S. Zeng, W. Huang, B. Han, F. Wu, G. He, M. Xiang. Mol. Divers. 17, 271 (2013).

[31] J. Li, J. Wang, Z. Xu, S. Zhu. ACS Comb. Sci. 16, 506 (2014).

[32] T. L. Pavlovskaya, F. G. Yarementko, V. V. Lipson, S. V. Shishkina, O. V. Shishkin, V. I. Musatov, A. S. Karpenko. Beilstein J. Org. Chem. 10, 117 (2014).

[33] G. Li, M. Wu, F. Liu, J. Jiang. Synthesis 47, 3783 (2015).

[34] A. Hazra, P. Paira, K. B. Sahu, S. Naskar, P. Saha, R. Paira, S. Mondal, A. Maity, P. Luger, M. Weber, N. B. Mondal, S. Banerjee. Tetrahedron Lett. 51, 1585 (2010).

[35] F. Felluga, C. Forzato, P. Nitti, G. Pitacco, E. Valentin, E. Zangrando. J. Heterocyclic Chem. 47, 664 (2010).

[36] G. Li, H. Wu, D. Kong, R. Liu, X. Zhou, F. Liu. New J. Chem. 38, 3350 (2014).

[37] Y. Toma, M. Kunigami, K. Watanabe, M. Higashi. J. Fluor. Chem. 189, 22 (2016).

[38] B. Gayen, A. Banerji, K. Dhara. Synth. Commun. 46, 293 (2016).

[39] K. B. Manjappa, Y.-T. Peng, W.-F. Jhang, D.-Y. Yang. Tetrahedron 72, 853 (2016).

[40] Z.-Y. Mao, Y.-W. Liu, P. Han, H.-Q. Dong, C.-M. Si, B.-G. Wei, G.-Q. Lin. Org. Lett. 20, 1090 (2018).

[41] U. Obst, V. Gramlich, F. Diederich, L. Weber, D. W. Banner. Angew. Chem. Int. Ed. 34, 1739 (1995).

[42] U. Obst, D. W. Banner, L. Weber, F. Diederich. Chem. Biol. 4, 287 (1997).

[43] U. Obst, P. Betschmann, C. Lerner, P. Seiler, F. Diederich. Helv. Chim. Acta 83, 855 (2000).

[44] P. Betschmann, S. Sahli, F. Diederich. Helv. Chim. Acta 85, 1210 (2002).

[45] K. Schärer, M. Morgenthaler, P. Seiler, F. Diederich. Helv. Chim. Acta 87, 2517 (2004).

[46] E. Schweizer, A. Hoffmann-Röder, K. Schärer, J. A. Olsen, C. Fäh, P. Seiler, U. Obst-Sander, B. Wagner, M. Kansy, F. Diederich. ChemMedChem 1, 611 (2006).

[47] L. M. Castelló, C. Nájera, J. M. Sansano, O. Larrañaga, A. de Cózar, F. P. Cossío. Adv. Synth. Catal. 356, 3861 (2014).

[48] E. García-Mingüens. C. Nájera, J. M. Sansano. Lett. Org. Chem. 15, 431 (2018).

[49] J. Hunter, C. M. Pask, V. Sridharan. Tetrahedron Lett. 57, 2774 (2016).

[50] K. Zhao, S.-L. Zhu, D.-Q. Shi, X.-P. Xu, S.-J. Ji. Synthesis 1793 (2010).

[51] M. Joucla, J. Mortier, J. Hamelin. Tetrahedron Lett. 26, 2775 (1985).

[52] T. Sengupta, S. Khamarui, S. Samanta, D. K. Maiti. Chem. Commun. 49, 9962 (2013).

[53] J. Mancebo-Aracil, C. Nájera, J. M. Sansano. Chem. Commun. 49, 11218 (2013).

[54] J. Mancebo-Aracil, C. Nájera, L. M. Castelló, J. M. Sansano, O. Larrañaga, A. de Cózar, F. P. Cossío. Tetrahedron 71, 9645 (2015).

[55] P. Cui, L. Xu, Z. Shi, L. Gan. J. Org. Chem. 76, 4210 (2011).

[56] Q. Lu, G. Song, J. P. Jasinski, A. C. Keeley, W. Zhang. Green Chem. 14, 3010 (2012).

[57] A. D. Lim, J. A. Codelli, S. E. Reisman. Chem. Sci. 4, 650 (2013).

[58] C. Chen, X. D. Li, S. L. Schreiber. J. Am. Chem. Soc. 125, 10174 (2003).

[59] V. Selva, O. Larrañaga, L. M. Castelló, C. Nájera, J. M. Sansano, A. de Cózar. J. Org. Chem. 82, 6298 (2017).

[60] L. M. Castelló, C. Nájera, J. M. Sansano, O. Larrañaga, A. de Cózar, F. P. Cossío. Org. Lett. 15, 2902 (2013).

[61] L. M. Castelló, C. Nájera, J. M. Sansano, O. Larrañaga, A. de Cózar, F. P. Cossío. Synthesis 47, 934 (2015).

[62] S. K. Ray, R. J. Biswas, A. Suneja, M. M. Sadhu, V. K. Sing. J. Org. Chem. 83, 2293 (2018).

[63] I. Coldham, S. Jana, L. Watson, C. D. Pilgram. Tetrahedron Lett. 49, 5408 (2008).

[64] M. F. Aly, H. Ardill, R. Grigg, S. Leong-Ling, S. Rajviroongit, S. Surendrakumar. Tetrahedron Lett. 28, 6077 (1987).

[65] L. M. Castelló, V. Selva, C. Nájera, J. M. Sansano. Synthesis 49, 299 (2017).

[66] I. Coldham, S. Jana, L. Watson, N. G. Martín. Org. Biomol. Chem. 7, 1674 (2009).

[67] R. Grigg, Z. Rankovic, M. Thorton-Pett, A. Somasunderam. Tetrahedron 49, 8679 (1993).

[68] S. Mantenutu, A. Cayuelas, G. Favi, O. A. Attanasi, F. Mantellini, C. Nájera, J. M. Sansano. Eur. J. Org. Chem. 4144 (2016). 